\title{
Review
}

\section{Brain Mechanisms of COVID-19-Sleep Disorders}

\author{
Oxana Semyachkina-Glushkovskaya ${ }^{1,2, * \mathbb{D}}$, Aysel Mamedova ${ }^{2}$, Valeria Vinnik ${ }^{2}$, Maria Klimova ${ }^{2}$, \\ Elena Saranceva ${ }^{2}$, Vasily Ageev ${ }^{2}$, Tingting Yu ${ }^{3,4}$, Dan Zhu ${ }^{3,4}$, Thomas Penzel 2,5,*(D) and Jürgen Kurths 1,2,6 \\ 1 Institute of Physics, Humboldt University, Newtonstrasse 15, 12489 Berlin, Germany; \\ juergen.kurths@pik-potsdam.de \\ 2 Department of Biology, Saratov State University, Atrakhanskaya Str. 83, 410012 Saratov, Russia; \\ mamedovayse195@gmail.com (A.M.); ler.vinnick2012@yandex.ru (V.V.); mari-1997@mail.ru (M.K.); \\ sophora68@mail.ru (E.S.); old-lon@yandex.com (V.A.) \\ 3 Wuhan National Laboratory for Optoelectronics, Britton Chance Center for Biomedical Photonics, \\ Huazhong University of Science and Technology, Wuhan 430074, China; yutingting@hust.edu.cn (T.Y.); \\ dawnzh@mail.hust.edu.cn (D.Z.) \\ 4 MoE Key Laboratory for Biomedical Photonics, Collaborative Innovation Center for Biomedical Engineering, \\ School of Engineering Sciences, Huazhong University of Science and Technology, Wuhan 430074, China \\ 5 Sleep Medicine Center, Charité-Universitätsmedizin Berlin, Charitéplatz 1, 10117 Berlin, Germany \\ 6 Potsdam Institute for Climate Impact Research, Telegrafenberg A31, 14473 Potsdam, Germany \\ * Correspondence: glushkovskaya@mail.ru (O.S.-G.); thomas.penzel@charite.de (T.P.); \\ Tel.: +79-271-155-157 (O.S.-G.); +49-30-450-513-013 (T.P.)
}

check for updates

Citation: SemyachkinaGlushkovskaya, O.; Mamedova, A.; Vinnik, V.; Klimova, M.; Saranceva, E.; Ageev, V.; Yu, T.; Zhu, D.; Penzel, T.; Kurths, J. Brain Mechanisms of COVID-19-Sleep Disorders. Int. J. Mol. Sci. 2021, 22, 6917. https:// doi.org/10.3390/ijms22136917

Academic Editors: Olga Dergacheva and Jhansi Dyavanapalli

Received: 4 May 2021

Accepted: 17 June 2021

Published: 28 June 2021

Publisher's Note: MDPI stays neutral with regard to jurisdictional claims in published maps and institutional affiliations.

Copyright: (c) 2021 by the authors. Licensee MDPI, Basel, Switzerland. This article is an open access article distributed under the terms and conditions of the Creative Commons Attribution (CC BY) license (https:/ / creativecommons.org/licenses/by/ $4.0 /)$.
Abstract: 2020 and 2021 have been unprecedented years due to the rapid spread of the modified severe acute respiratory syndrome coronavirus around the world. The coronavirus disease 2019 (COVID-19) causes atypical infiltrated pneumonia with many neurological symptoms, and major sleep changes. The exposure of people to stress, such as social confinement and changes in daily routines, is accompanied by various sleep disturbances, known as 'coronasomnia' phenomenon. Sleep disorders induce neuroinflammation, which promotes the blood-brain barrier (BBB) disruption and entry of antigens and inflammatory factors into the brain. Here, we review findings and trends in sleep research in 2020-2021, demonstrating how COVID-19 and sleep disorders can induce BBB leakage via neuroinflammation, which might contribute to the 'coronasomnia' phenomenon. The new studies suggest that the control of sleep hygiene and quality should be incorporated into the rehabilitation of COVID-19 patients. We also discuss perspective strategies for the prevention of COVID-19-related BBB disorders. We demonstrate that sleep might be a novel biomarker of BBB leakage, and the analysis of sleep EEG patterns can be a breakthrough non-invasive technology for diagnosis of the COVID-19-caused BBB disruption.

Keywords: COVID-19-sleep disorders; brain mechanisms; the blood-brain barrier permeability

\section{The 'Coronasomnia' Phenomenon}

2020 and 2021 have been unprecedented years due to the modified severe acute respiratory syndrome (SARS) coronavirus (SARS-CoV-2), which spreads rapidly to all continents, leading to a pandemic. The number of cases of coronavirus disease 2019 (COVID-19) continues to rise globally, and between 31 December 2019 and 29 April 2021, 148,999,876 people worldwide have been infected with 3,140,115 deaths (WHO, 2021: https: / / covid19.who.int, accessed on 1 May 2021). The COVID-19 pandemic has placed an enormous burden on the global healthcare system and the entire population in every country is at risk of infection [1]. SARS-CoV is a novel virus that caused the first major pandemic of the new millennium in 2003 [2-6].

Nowadays, the modified COVID-19 causes atypical infiltrated pneumonia with many neurological symptoms and sleep disorders [7-9]. The current COVID-19 pandemic significantly affects our daily activities due to social distancing, which is impacting work, social, educational, and entertainment activities [10-12]. Indeed, for the last 1.5 years, 
the international news is focused mainly on health, employment, finance, and economic recession associated with the COVID-19 pandemic. These uncertainties have exposed many people to stress, such as social confinement, limited daylight exposure, and changes in daily routines, which are also associated with various sleep disturbances, known as the 'coronasomnia' phenomenon (Figure 1) $[11,13,14]$. Notice that it is not a new phenomenon. Several epidemiological studies reported that insufficient sleep, poor sleep quality, insomnia, sleep apnea, and disturbances of sleep-wake schedules are typical manifestations of physical and emotional morbidity in a worldwide pandemic [15]. Several studies have previously documented the impact on sleep of major events, such as earthquakes, floods, wild fires, and war-time [16,17].

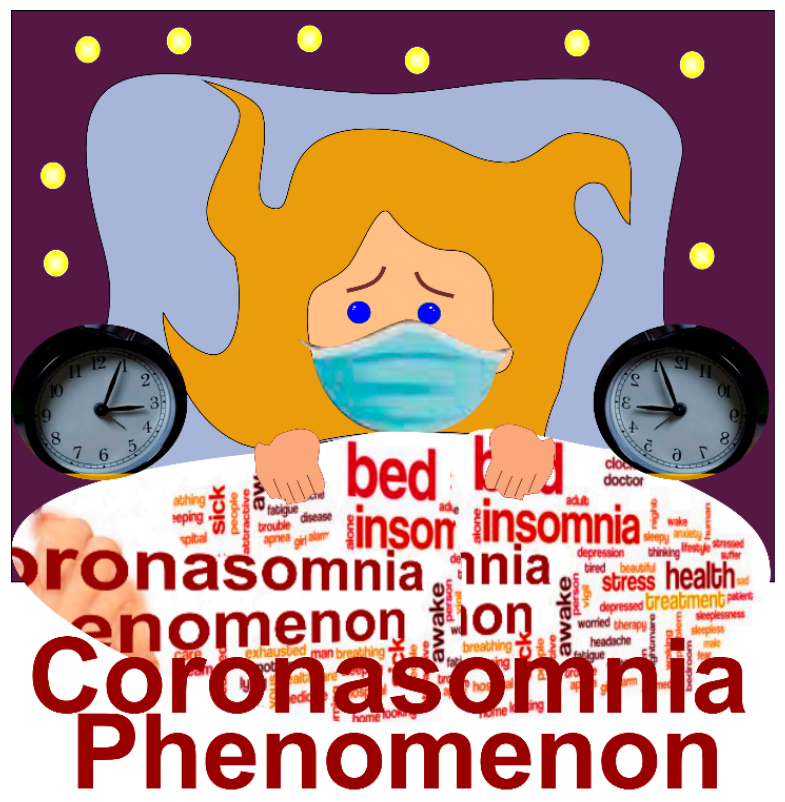

Figure 1. The 'coronasomnia' phenomenon has been recently described as COVID-19-related sleep disorders, including insufficient sleep, poor sleep quality, insomnia, and disturbances of sleep-wake schedules associated with physical and emotional morbidity in the COVID-19 pandemic.

The first studies of COVID-19-associated sleep disorders were published in China. Huang and Zhao collected information from a survey of 7236 volunteers and reported $18 \%$ of poor sleep quality [10]. Later, the sleep disorders in patients with COVID-19 have also been highlighted in several other publications from different countries [9,18-29]. These studies examined the effect on sleep of SARS-CoV-2 infection and confounders related to isolation, quarantine, anxiety, stress, or financial losses. In Europe, symptoms of insomnia could be related to psychosocial factors, such as the confinements due to quarantine [19]. In Italy, COVID-19-related anxiety was highly associated with sleep disorders. In a survey of 2291 Italians, 57.1\% reported poor sleep quality [20]. In the International COVID-19 Sleep Study, COVID-19-mediated insomnia, nightmares, sleep apnoea, fatigue, exhaustion, and rapid eye moved (REM) sleep behavior disorder have shown [15]. There is the hypothesis that sleepiness and REM sleep behavior disorder might be related to COVID-19 per se, whereas insomnia might be related mainly to confinement, anxiety, and other psychosocial factors [16].

We found 226 relevant publications out of 652 papers on COVID-19 and sleep disorders until 30 April 2021 in PubMed. Many of these publications are reviews or clinical studies among healthcare workers. Surveys have been completed in the general public in China [10,29], France [30], Italy [11], and USA [31]. Insomnia and other sleep disorders were frequently reported, and there were associations with confinement, physical exercise, social interactions, and other aspects [14]. A recent 1-month cross-sectional observational study of 180 medical staff in China who were treating patients with COVID-19 during 
January and February 2020 found higher levels of anxiety associated with different types of sleep disturbances [32].

The COVID-19-sleep disorders are a major problem of rehabilitation of patients after infection. However, the exploration of mechanisms underlying the 'coronasomnia' phenomenon is still in its infancy. Most research related to COVID-19-sleep disorders is obtained on the effect of lookdown or confinement during the pandemic. There is even a meta-analysis on the many studies published [33] and one case report [34]. However, if we want to know the association of a PCR diagnosed COVID-19 infection and sleep problem, then there are no studies until now. Here, we review important findings and trends in sleep research in 2020-2021, demonstrating how sleep disorders can open the blood-brain barrier (BBB) for inflammatory factors, which might contribute to the 'coronasomnia' phenomenon. We also highlight the mechanisms of COVID-19-induced BBB disruption and neuroinflammation that can be an additional reason for COVID-19-related sleep disorders. Finally, we discuss new perspective strategies for the prevention of COVID-19-related BBB disorders. We demonstrate that sleep might be a novel biomarker of the BBB leakage, and the analysis of EEG sleep patterns can be a breakthrough non-invasive technology for the diagnosis of COVID-19-caused BBB disruption.

\section{Sleep Loss-Associated Neuroinflammation and the Blood-Brain Barrier Disruption}

Sleep deprivation in duration and/or quality is a common type of COVID-19-related sleep disorder [12,19-30]. We do not know how sleep restriction affects the brain. However, there is emerging evidence that the major complication of sleep loss is neuroinflammation, which induces BBB disruption (Table 1). Indeed, sleep loss per se, including sleep deprivation, sleep restriction, sleep fragmentation, or sleep apnea in human and rodents induces a systemic low-grade inflammation characterized by the release of several molecules, such as cytokines, chemokines, and acute-phase proteins; all of them can promote changes in cellular components of the BBB, particularly on brain endothelial cells [35-46]. In this session, we discuss the role of inflammatory mediators that increase during sleep loss and how these changes may alter the BBB permeability as well as we analyze hypothetical mechanisms by which sleep deprivation may induce the BBB disruption, emphasizing the regulatory effect of inflammatory molecules on tight junction proteins.

The first results on sleep deprivation and brain inflammation were published in the early 2000s [47,48]. These findings report that the low-grade systemic inflammation induced by sleep loss is characterized by a subtle but sustained increase in peripheral levels of pro- and inflammatory mediators. Further experimental studies demonstrated that acute and chronic sleep loss is associated with an increased level of proinflammatory mediators, such as tumor necrosis factor- $\alpha$ (TFN- $\alpha)$, interleukin-1 $\beta$ (IL-1 $1 \beta)$, IL-6, IL-17A, and Creactive protein (CRP) as well as with an increased level of immune-derived inflammatory mediators, such as cyclooxygenase-2 (COX-2), nitric oxide synthase (NOS), endothelin1 (ET-1), vascular endothelial growth factor (VEGF), and insulin-like growth factor-1 (IGF-1) [35,39,44,49-51].

C-reactive protein (CRP) and high-sensitivity C-reactive protein (hs-CRP) are markers of systemic inflammation and may serve as biomarkers of OSA [52,53]. Meta-analysis on the total of 1297 subjects revealed that serum CRP levels in the OSA group were $1.98 \mathrm{mmol} / \mathrm{L}$ higher than those in the control group (95\% confidence interval: 1.39-2.58, $p<0.01)$. Similarly, serum hs-CRP levels in the OSA group were $1.57 \mathrm{mmol} / \mathrm{L}$ higher than that in the control group (95\% confidence interval: 0.96-2.18, $p<0.01$ ) [52].

Recently, it has been discovered that sleep deprivation increases the BBB permeability to inflammatory mediators, immune cells, and exogenous tracers in humans and rodents $[35,36,38,39,41-43,45,50,54-56]$. 
Table 1. The effects of sleep deprivation on the blood-brain barrier functions.

\begin{tabular}{|c|c|c|}
\hline References & Sleep Loss Models & The Effects of Sleep Loss on the BBB Permeability \\
\hline $\begin{array}{l}\text { Medina-Flores F. et al. } \\
\text { (2020) [38] }\end{array}$ & $\begin{array}{l}\text { Wistar rats were sleep-restricted } 20 \text { h daily with } 4 \mathrm{~h} \text { sleep } \\
\text { recovery for } 10 \text { days. }\end{array}$ & Sleep loss disrupts pericyte-brain endothelial cell interactions. \\
\hline $\begin{array}{l}\text { Hurtado-Alvarado G. } \\
\text { et al. (2016) [39]. } \\
\text { Review }\end{array}$ & $\begin{array}{l}\text { Acute and chronic sleep deprivation, sleep restriction and } \\
\text { sleep fragmentation. }\end{array}$ & $\begin{array}{l}\text { Sleep loss induces a low-grade systemic inflammation characterized by the release of several } \\
\text { molecules, such as cytokines, chemokines, and acute-phase proteins; all of them may promote } \\
\text { changes in cellular components of BBB, particularly on brain endothelial cells. }\end{array}$ \\
\hline $\begin{array}{l}\text { Hurtado-Alvarado G. } \\
\text { et al. (2018) [35] }\end{array}$ & $\begin{array}{l}\text { Mice were sleep-restricted during } 10 \text { days using the flowerpot } \\
\text { technique for } 20 \mathrm{~h} \text { per day with } 4 \mathrm{~h} \text { of daily sleep opportunity. }\end{array}$ & $\begin{array}{l}\text { Cytokines may play a key role in modulating BBB function during sleep restriction via the } \\
\text { overexpression of Iba- } 1, \text { MMP-9 and A2A adenosine receptors. }\end{array}$ \\
\hline $\begin{array}{l}\text { Hurtado-Alvarado G. } \\
\text { et al. (2017) [56] }\end{array}$ & $\begin{array}{c}\text { Male Wistar rats were sleep restricted using the modified } \\
\text { multiple platform method for } 10 \text { days, with a daily schedule of } \\
\text { 20-h sleep deprivation plus } 4 \text {-h sleep recovery at their } \\
\text { home-cages. }\end{array}$ & $\begin{array}{l}\text { Chronic sleep restriction disrupts interendothelial tight junctions in the hippocampus and increases } \\
\text { BBB permeability to fluorescein-sodium, and decreases interendothelial junction complexity by } \\
\text { increasing the frequency of less mature end-to-end and simply overlap junctions, even after sleep } \\
\text { recovery, as compared to intact controls. Chronic sleep loss also induces the formation of clefts } \\
\text { between narrow zones of adjacent endothelial cell membranes in the hippocampus. }\end{array}$ \\
\hline $\begin{array}{l}\text { Gómez-González B. } \\
\text { (2013) [55] }\end{array}$ & $\begin{array}{l}\text { REM sleep restriction was induced by the multiple platform } \\
\text { technique; male rats were REM sleep-restricted } 20 \mathrm{~h} \text { daily } \\
\text { (with } 4 \text { h sleep opportunity) for } 10 \text { days; control groups } \\
\text { included large platform and intact rats. }\end{array}$ & $\begin{array}{l}\text { REM sleep restriction increased BBB permeability to Evans blue in the whole brain. Brief periods of } \\
\text { sleep recovery rapidly and effectively restored the severe alteration of BBB function by reducing } \\
\text { BBB transfer of Evans blue. The mechanism of BBB breakdown involved increased caveolae } \\
\text { formation at brain endothelial cells. REM sleep regulates the physical barrier properties of BBB. }\end{array}$ \\
\hline $\begin{array}{l}\text { Hurtado-Alvarado G. } \\
\text { et al. (2016) [54] }\end{array}$ & $\begin{array}{l}\text { The chronic sleep restriction of male Wistar rats } \\
\text { during } 10 \text { days. }\end{array}$ & $\begin{array}{l}\text { Sleep restriction increased BBB permeability to FITC-dextrans and Evans blue, and the effect was } \\
\text { reverted by the administration of selective A2A adenosine receptor antagonist (SCH58261) in } \\
\text { almost all brain regions excluding the cerebellum. Sleep restriction increased the expression of A2A } \\
\text { adenosine receptor only in the hippocampus and basal nuclei without changing the expression of } \\
\text { adenosine-synthesizing enzyme (CD73) in all brain regions. Sleep restriction reduced the expression } \\
\text { of tight junction proteins (claudin-5, occludin, ZO-1) in all brain regions, except in the cerebellum; } \\
\text { and SCH58261 restored the levels of tight junction proteins in the cortex, hippocampus and basal } \\
\text { nuclei. Sleep restriction-induced neuroinflammatory markers (GFAP and Iba-1) overexpression that } \\
\text { was attenuated with the administration of SCH58261. }\end{array}$ \\
\hline
\end{tabular}


Table 1. Cont.

References

Sleep Loss Models

Daulatzai M.A. (2016)

[42]. Review

Obstructive sleep apnea

Lim D.C. and Pack A.I

(2014) [41]. Review

Obstructive sleep apnea

Obstructive sleep apnea. The two groups of volunteers were selected, a group of patients suffering newly diagnosed severe Voirin A.C. et al. obstructive sleep apnea (AHI $>30 / \mathrm{h}$ ) and a group showing no (2020) [43] sleep apnea (AHI $<5 / \mathrm{h})$. The human in vitro BBB model of endothelial cells (HBEC-5i) with sera of patients with and without obstructive sleep apnea was studied.

Benedict C. et al. (2014) Healthy young men were divided on 2 groups including either [45] 8-h of nocturnal sleep [22:30-06:30] and total sleep deprivation.

The sleep fragmentation device used in this study. The device consists of a cylindrical Plexiglass ${ }^{\circledR}$ chamber divided into two separate compartments. The floor of the chamber is a disc that is programmed to rotate at specific intervals. In this study, disc rotations were confined to the $12 \mathrm{~h}$ light period, and consisted of an $8 \mathrm{~s}$ rotation once every $30 \mathrm{~s}$, on average. The direction of the disc rotation was randomized, and the precise placement

Opp M.R. et al. (2015) of the $8 \mathrm{~s}$ rotation within the $30 \mathrm{~s}$ period was varied to prevent [46]

behavioral adaptation by a mouse to disc movements.

Sleeping mice wake up when the disc rotates, whereas awake mice continue their normal behavior. During the $12 \mathrm{~h}$ dark period, there was no disc rotation, and mice were allowed spontaneous behavior. Mice were housed in the sleep disruption devices, one mouse in each compartment, for 3 days of habituation prior to beginning the sleep fragmentation protocol.
Acute and chronic sleep deprivation, sleep restriction, and sleep fragmentation.

\section{The Effects of Sleep Loss on the BBB Permeability}

Obstructive sleep apnea is a risk factor triggering neuroinflammation and oxidative-nitrosative stress that in turn decrease nitric oxide and enhance endothelin, amyloid- $\beta$ deposition, cerebral amyloid angiopathy, and BBB disruption.

Cyclical intermittent hypoxia is a stressor that disrupts BBB via molecular responses already known to occur in either obstructive sleep apnea patients or animal models of intermittent hypoxia.

After incubation with sera from patients with obstructive sleep apnea, there was a loss of integrity in the human in vitro BBB model; this was reflected by an increase in permeability $(43 \% ; p<0.001)$ and correlated with a $50 \%$ and $40 \%$ decrease in tight junction protein expression of $\mathrm{ZO}-1$ and claudin- 5 , respectively. There was an upregulation in Pgp protein expression (52\%) and functionality and a downregulation in BCRP expression (52\%). These results demonstrate that severe BBB disorder after exposure to sera from patients with obstructive sleep apnea was reflected by BBB opening.

Acute sleep deprivation increases serum levels of neuron-specific enolase (NSE) and S100 calcium-binding protein B (S-100B) in healthy young men.

The sleep fragmentation disrupted the BBB and increased tumor necrosis factor- $\alpha$ transport in aged mice but not in young mice.

Authors summarize research on the sleep-BBB interactions in five sections: (1) the structural basis enabling the BBB to serve as a huge regulatory interface; (2) BBB transport and permeation of substances participating in sleep-wake regulation; (3) the circadian rhythm of BBB function; (4) the effect of experimental sleep disruption maneuvers on BBB activities, including regional heterogeneity, possible threshold effect, and reversibility; and (5) implications of sleep disruption-induced BBB dysfunction in neurodegeneration and CNS autoimmune diseases. 
Hurtado-Alvarado et al. observed that sleep restricted C57BL/6 mice exhibited an increase in the BBB permeability to Na-fluorescein, $10 \mathrm{kDa}$ dextrans, and Evans blue in comparison to the same strain control groups. Moreover, there were differences in the distribution of the tracers in the brain [35]. Na-fluorescein and $10 \mathrm{kDa}$ dextrans, reflecting the BBB leakage to low molecular weight [57], was presented a widespread deposition in the parenchyma of the cortex, hippocampus, and vermis in C57BL/6 sleep-restricted mice [35]. In contrast, the larger tracer, Evans blue $65.8 \mathrm{kDa}$, mimicking the BBB breakdown to proteins [57], was presented mostly in the hippocampus.

Gómez-González et al. 2013 reported that 10 days of sleep restriction in a schedule of 20 daily hours of sleep deprivation using the multiple platform technique plus $4 \mathrm{~h}$ of sleep opportunity induce a full suppression of REM sleep and around $30 \%$ loss of nonREM sleep [55]. This finding showed a widespread breakdown of the BBB. Interestingly, the brief periods of sleep opportunity (40 to $120 \mathrm{~min}$ ) induced a progressive recovery of the BBB permeability to Evans blue $(65.8 \mathrm{kDa})$ in the majority of brain regions studied, with the exception of the hippocampus and the cerebellum. In a subsequent study, mice were subjected to sleep restriction for 6 days in a rotatory bar for $12 \mathrm{~h}$ per day. Sleep restriction induced REM sleep deprivation in the first 3 days with partial REM sleep recovery afterward [50]. Under these conditions, the increased BBB permeability to low molecular-weight tracer-sodium fluorescein $(10 \mathrm{kDa})$ and the decreased mRNA levels of the tight junction proteins claudin-5, zonula occludens-2, and occludin was observed in all regions of the brain. It is important to note that the sleep recovery by $24 \mathrm{~h}$ fully reverted the BBB permeability in mice [50].

Sleep disturbances also increase the BBB permeability in humans [41-43,45]. Indeed, acute sleep deprivation induces an increase in the serum levels of neuron-specific enolase and S100 calcium-binding protein B (S-100B) in healthy young men [45]. Obstructive sleep apnea is a risk factor that triggers neuroinflammation and oxidative-nitrosative stress. That in turn, decreases nitric oxide and enhances endothelin, amyloid- $\beta$ deposition, cerebral amyloid angiopathy, and BBB disruption [42]. Voirin A.C. et al. used the human in vitro BBB model of endothelial cells (HBEC-5i) with sera of patients with and without obstructive sleep apnea [43]. They demonstrated that obstructive sleep apnea is accompanied by BBB disruption and a decrease in tight junction protein expression of zonula occludes- 1 and claudin- 5 .

There are age-related differences in the BBB dysfunction induced by sleep loss. Indeed, sleep fragmentation disrupts the BBB and increases the tumor necrosis factor- $\alpha$ transport in elderly mice but not in young mice [47].

Previous reports have shown that the mechanism of BBB opening mediated by sleep loss involves both tight junction disentangle and the increase of pinocytosis in the cerebral endothelial cells $[50,55,56]$. Medina-Flores F et al. using a model of chronic sleep loss during 10 days showed that sleep deprivation disrupts pericyte-brain endothelial cell interactions [38]. Chronic sleep restriction disrupts interendothelial tight junctions in the hippocampus, causes a BBB leakage to fluorescein-sodium and decreases the interendothelial junction complexity. Chronic sleep deprivation also induces the formation of clefts between narrow zones of adjacent endothelial cell membranes in the hippocampus [56].

Chronic sleep restriction causes an increase of paracellular permeability of the BBB to the small tracers sodium fluorescein and biotin that is accompanied by reducing the expression of endothelial and inducible NOS, endothelin1, glucose transporter in cerebral endothelium and decreases 2-deoxy-glucose uptake by the brain [50]. The expression of several tight junction proteins also decreases, whereas the level of cyclooxygenase- 2 increases. Chronic sleep restriction for $6 \mathrm{~d}$ is sufficient to impair the BBB structure and function, although the increase of paracellular permeability returns to baseline after $24 \mathrm{~h}$ of recovery sleep [50].

Cytokines may play a key role in modulating the BBB function during sleep restriction via the overexpression of the tumor necrosis factor $\alpha$ [48,58], interleukin-1 beta [59], interleukin-6 [48,60], interleukin-17 [61], C reactive protein [61,62], allograft inflammatory factor 1 (Iba-1) [33], matrix metalloproteinase 9 (MMP-9) [35] and A2A adenosine receptors [35]. There are two reviews discussing that sleep deprivation induces a low- 
grade systemic inflammation characterized by the release of inflammatory molecules, such as cytokines, chemokines, and acute-phase proteins, which promote changes in cellular components of the BBB [36,39]. The administration of the selective A2A adenosine receptor antagonist (SCH58261) protects BBB injuries after sleep restriction in almost all brain regions, excluding the cerebellum [54]. Sleep restriction reduces the expression of tight junction proteins (claudin-5, occludin, zonula occludin-1) in all brain regions, except in the cerebellum; and SCH58261 restores the levels of tight junction proteins in the cortex, hippocampus and basal nuclei. Sleep restriction induces neuroinflammatory markers (GFAP and Iba-1) overexpression that was attenuated with the administration of SCH58261 [54].

Overall, sleep loss causes a low-grade inflammation of the brain, which facilitates the BBB breakdown that can partly explain the 'coronasomnia' phenomenon. Indeed, COVID-19-related sleep disorders might contribute to the BBB opening that can be a door for COVID-19 entry into the brain and further hyper-inflammation of the CNS. Figure 2 illustrates how sleep disorders can open the BBB and contributes SARS-CoV-2 entry into the brain via neuroinflammation induced by sleep deprivation (Figure 2).

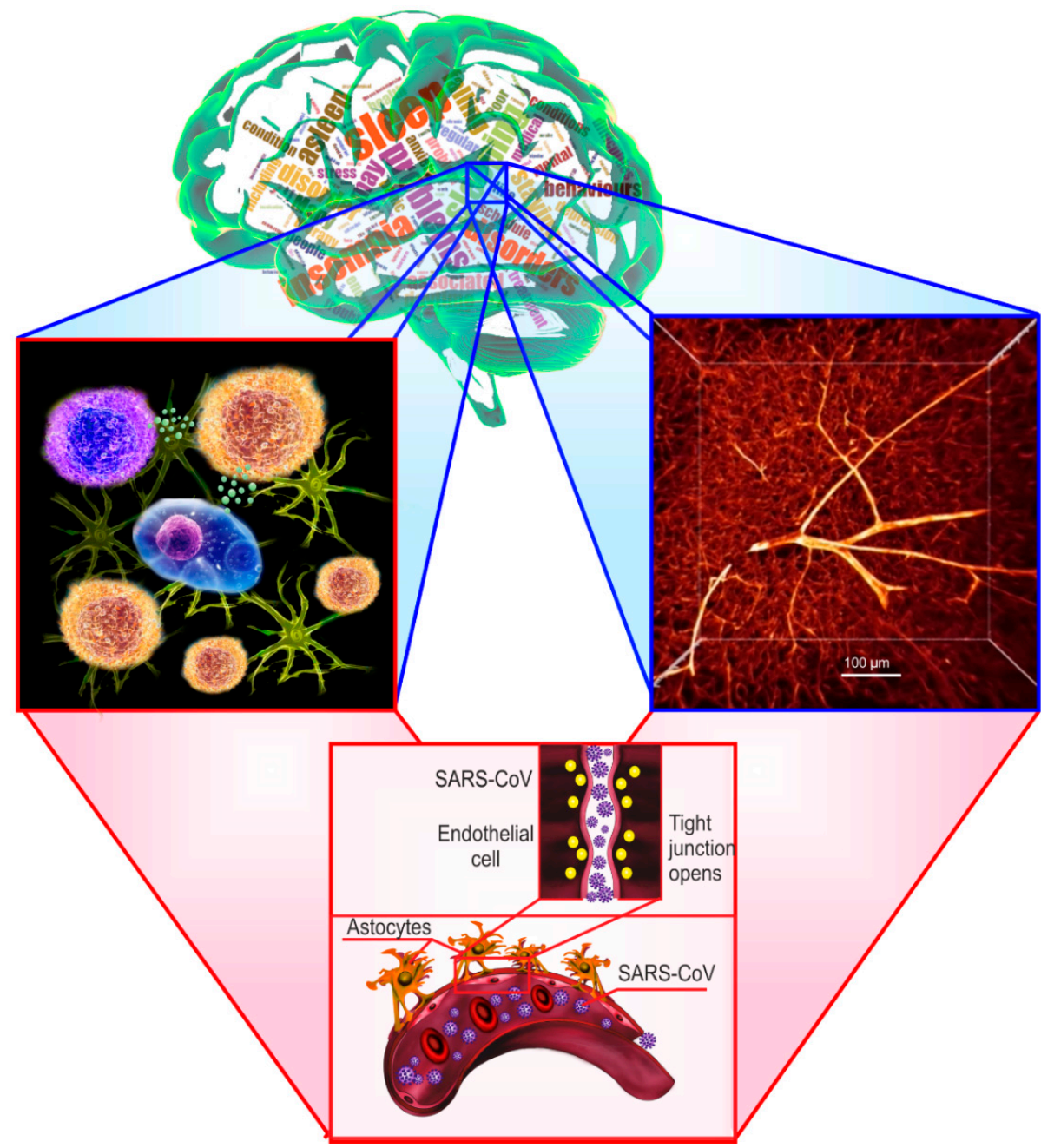

Figure 2. Illustration of the blood-brain barrier (BBB) disruption induced by sleep-related disorders. Middle upper figure demonstrates the various sleep disturbances, including insomnia, sleep deprivation, sleep apnea, associated with the BBB breakdown. The left figure shows that sleep loss causes low-grade inflammation of the brain, which facilitates the BBB disruption. Right (two-photon imaging of the brain capillaries filled by tetramethylrhodamine isothiocyanate-dextran $70 \mathrm{kDa}$ ) and the middle lower squares demonstrate the cerebral blood vessels damaged by cytokines leading to the BBB opening. 


\section{Circadian Regulation of the Blood-Brain Barrier Permeability to Cytokines}

The circadian rhythm is a biological clock that endogenously oscillates with a period of roughly $24 \mathrm{~h}$. There is recognition of the importance that the central circadian pacemakers in mammals are both the suprachiasmatic nucleus and the BBB cells, which have autonomous circadian rhythms driven by molecular clocks [37,63-65]. Moreover, the large cerebral blood vessels themselves exhibit the circadian clock [66,67]. In the following, we highlight recent evidence demonstrating that the BBB permeability to cytokines depends on the time of day that can be important for a better understanding of the mechanisms underlying COVID-19-associated sleep disorder.

Upon invasion of bacteria and viruses, the immune system is immediately activated, producing inflammatory mediators, including pro-inflammatory cytokines, such as tumor necrosis factor (TNF- $\alpha$ ), interleukins, IL-1 $\beta / \mathrm{IL}-6$, and inflammatory mediators, prostaglandins (PGs) and leukotrienes. This immune response evokes an acute inflammatory process (hours to days) to clear the pathogens from the infected tissues.

The accumulating evidence suggests that the severity of COVID-19 is associated with an increased level of inflammatory mediators, including cytokines and chemokines such as interleukins, TNF, granulocyte colony-stimulating factor (G-CSF), monocyte chemoattractant protein-1, macrophage inflammatory protein 1 alpha, C-reactive protein, ferritin, and D-dimers in blood upon SARS-CoV-2 infection [68-72]. Note that among the elevated inflammatory mediators, the blood IL-6 level is highly correlated with the disease mortality when COVID-19 survivors and non-survivors are compared [73,74]. This fact suggests that fatal COVID-19 is characterized as a cytokine release syndrome that is induced by a cytokine storm with high mortality [75-77].

The entry of some cytokines, such as tumor necrosis factor (TNF- $\alpha$ ) [78,79], interleukins 6 (IL 6) [80,81], and IL-1 $\alpha$ [82] into the brain undergo significant circadian oscillations (Figure 2).

The TNF- $\alpha$ is a cytokine used by the immune system for cell signaling. When macrophages detect an infection, they release TNF to alert other immune system cells as part of an inflammatory response. Pan et al. showed that the spinal cord, but not the brain, demonstrate a circadian rhythm in the uptake of TNF $\alpha$ [78]. The greatest TNF $\alpha$ uptake occurs between Zeitgeber time (ZT) 20-ZT23 (Figure 3). This pattern is similar to that of leptin but different from that of interleukin-1. The circadian rhythm of the influx of TNF $\alpha$ into this region of the CNS suggests a functional role for the spinal cord in the physiological actions of TNF $\alpha$. TNF $\alpha$ transport across the BBB is abolished in receptor knockout mice [79].

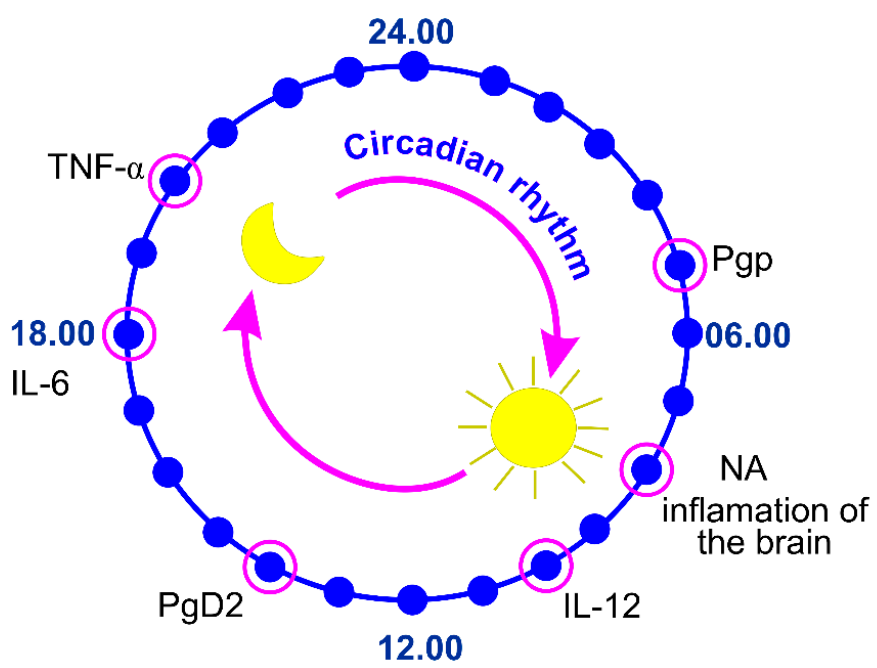

Figure 3. The biological clock of the blood-brain barrier permeability to cytokines (TNF- $\alpha$, IL-6, IL- $1 \alpha$ ) and regulating their activity factors, such as hormones (NA and PGD2) and permeabilityglycoprotein multidrug transporter (Pgp). 
Interleukin-6 is a cytokine with pleiotropic actions in both the periphery of the body and the CNS. Altered IL-6 secretion has been associated with inflammatory dysregulation and several adverse health consequences [83]. The intense BBB permeability to radioactively labeled murine and human IL-6 occurs in the evening, while the peak of diurnal uptake of circulating 125I (I-IL) by the brain and the spinal cord is observed at $08.00 \mathrm{~h}-12.00 \mathrm{~h}$ (Figure 2) [70-72].

This diurnal variation in the rate of uptake of cytokines by the CNS could underlie differences in potency when given at different times of the day.

The activation of cytokines critically depends on endogenously produced prostaglandin D2 (PGD2) that exhibits daily oscillations in the rat CSF, peaking at 14:00 [84-87].

Evidence indicates that noradrenaline (NA) elicits anti-inflammatory actions in the CNS and consequently may play a neuroprotective role where inflammatory events contribute to the CNS pathology [88,89].

A study by Staedtke et al. using subcutaneously implanted osmotic pumps to continuously release NA revealed that epinephrine may fuel the cytokine storms [90]. Luo and $\mathrm{Li}$ analyzed 206 patients who were diagnosed with COVID-19 and suffered a rescue treatment with epinephrine at the Tongji Hospital in Wuhan, China, from January 27 to March 1, 2020. They noticed that only $4 / 206$ (2\%) of patients were survivors and discharged from the hospital eventually [91]. The severity of the disease may account mostly for the poor outcome. However, as expected from the established role of NA in fueling the cytokine storms, the aggravated cytokine storms may also play a role in the failure of the rescue.

The brain areas with the highest concentration of noradrenergic nerve terminals and NA have a circadian rhythm in their content of NA in rabbits, rats, and cats [92]. The anterior and lateral hypothalamus [93] and cervical spinal cord [94], midbrain [95], and caudate nucleus [96], medial lower brain stem [97], and frontal cortex [98] all have significant circadian variations in their NA content. These brain regions have their highest NA level during the night in rats, a nocturnal animal, and during the day in rabbits and cats [92]. The noradrenergic locus coeruleus neurons fire in a wake-dependent manner; they are highly active during wake, slow-firing during non-REM sleep, and almost completely quiescent during REM sleep $[99,100]$.

Glucocorticoids play an important role in regulation of the circadian clock via modulating the suprachiasmatic nucleus response and synthesis of various systemic factors, including cytokines [101,102]. Circadian control of glucocorticoid production and secretion involves a central pacemaker in the hypothalamus, the suprachiasmatic nucleus, as well as a circadian clock in the adrenal gland itself. The rhythmically released glucocorticoids, in turn, might contribute to the synchronisation of the cell-autonomous clocks in the body and interact with them to time physiological dynamics in their target tissues around the day.

The BBB consists of vascular endothelial cells connected to each other by tight junctions that form a lumen for blood flow. Endothelial cells express a set of transporters to move molecules both into and out of the brain $[103,104]$, which include permeabilityglycoprotein multidrug transporter (also known as Pgp, multidrug resistance protein 1, or ATP-binding cassette sub-family B member 1), an ATP-dependent efflux pump that can pump both endogenous molecules and exogenous compounds back into the lumen of blood vessels $[105,106]$. The surface of endothelial cells exposed to the brain is surrounded by specialized projections (endfeet) of astrocytic glial cells.

Pgp regulates the permeability of many endogenous and exogenous molecules across the BBB in a circadian manner. Indeed, the peak concentration of quinidine, a substrate of Pgp, in the CSF and ISF of rats is higher between ZT0, ZT4, and ZT8 [107]. This suggests that Pgp is more active during periods of wakefulness. Pgp activity is increased during times of wakefulness also in flies [108]. This is due, in part, to active efflux through Pgp-like transporter during the day [108]. Loss of the circadian clock inhibits the nighttime increase in permeability, suggesting that the clock normally inhibits Pgp-like transporters at night to allow increased permeability [108]. Interestingly, genetic inhibition of Pgp transporters in 
flies led to increased sleep, possibly by increasing central nervous system (CNS) permeation of peripheral sleep-promoting molecules [109].

\section{The COVID-19 Attack on the Blood-Brain Barrier Integrity}

An alternative route of COVID-19 to the CNS is through the dissemination of SARSCoV-2 into the systemic circulatory system following the infection of the respiratory tract [110]. In this pathway, SARS-CoV-2 may spread to other target tissues and organs with cerebral blood flow. However, the virus cannot simply migrate from the capillaries of the systemic circulatory system to the brain through endothelial cells due to the unique physiology of the BBB. The BBB is a crucial immunological feature of the CNS. Composed of many cell types, the $\mathrm{BBB}$ is both a structural and functional roadblock to microorganisms, such as bacteria, fungi, viruses, or parasites. As a result, the BBB is a key regulator of antigens entry into the CNS and exists at the interface of blood vessels and interstitial fluid throughout the brain.

Thus, to infect the brain via the hematogenous route, the virus must first bypass the BBB. Human angiotensin I-converting enzyme-2 (ACE2) and transmembrane protease serine 2 are two surface membrane receptors that are involved in SARS-CoV-2 entry into host target cells [111-113]. Neuropilin-1 (NRP-1), a member of a family of signaling proteins, was shown to serve as an entry factor and potentiate SARS-CoV-2 infectivity $[114,115]$. Expression of the ACE2 receptor [116] and NRP1 [117] has also been confirmed in human brain microvascular endothelial cells (BMVECs), making them potential targets for SARSCoV-2 infection. To date, at least one study has described via post-mortem analysis of the brain by transmission electron microscopy the presence of viral-like proteins inside BMVECs in the frontal lobe of a patient who died from COVID-19 [118]. This provides the first direct evidence that SARS-CoV-2 can infect BMVECs of the BBB [119].

Limited evidence exists about the effects of other types of coronaviruses on the BBB. Laboratory animal studies have shown that the coronavirus mouse hepatitis virus (MHV) induces the BBB breakdown regulated by a decrease in the tight junction proteins occludin and zonule occludens 1, resulting in a CNS infection [120]. In the owl monkey (Aotus trivirgatus), infection with the murine coronavirus (strain JHM) (MHV-JHM) combined with outer membrane protein gene (omp1) (JHM OMP1) via intracerebral, intranasal, or intravenous inoculation resulted in a CNS infection, as evidenced by the detection of viral products in the brains of all animals, predominantly in the blood vessels and perivascular regions $[119,121,122]$. This suggests that a coronavirus can infect and replicate in endothelial cells to bypass the BBB. Moreover, in vitro studies later demonstrated that the coronavirus JHM OMP1 can infect cultured BMVECs isolated from humans and rhesus macaques [119,123], providing further evidence that certain coronaviruses can infect BMVECs of the BBB.

Preliminary results suggest that SARS-CoV-2 can invade BMVECs in humans [118]. In addition, a recent study indicates that the spike protein of SARS-CoV-2 can induce an increase in the BBB permeability in a BBB-on-a-chip in vitro system [124]. Most importantly, emerging evidence from human studies indicates that SARS-CoV-2 induces BBB dysfunction in humans. Bellon et al. recently reported that, from 31 COVID-19 patients with neurological manifestations, 58\% presented an increase in the BBB permeability [125], providing the first-in-human evidence that SARS-CoV-2 induces a BBB dysfunction. In this study, it was unclear whether the disruption of the BBB was a direct result of SARS-CoV-2 infection or this damage was a secondary response to neuroinflammation. More research is needed to elucidate the mechanisms by which this virus bypasses the BBB and enters the brain and whether patients with underlying conditions that affect the BBB are at an increased risk of brain infections [119]. 
Human neurotropic RNA viruses have evolved as opportunistic pathogens that can bypass the BBB and gain entry into the CNS by several mechanisms: (a) paracellular transport via a leaky BBB, (b) transcellular transport by direct infection of the cerebrovascular endothelial cells, or (c) transport via extracellular vesicles, a form of «Trojan horse» trafficking. A recent study on the Japanese encephalitis virus (JEV) (an RNA virus) suggests that the paracellular mode of trafficking could be one of the potential routes of entry into the CNS. JEV infected mast cells release chymase, a vasoactive protease, which cleaves TJ proteins, including zona occludens- 1 and 2 , claudin- 5 , and occludin, breaking down the BBB and facilitating the entry of JEV into the CNS [126]. During transcellular migration, viruses invade host endothelial cells to cross the BBB. During paracellular migration, viruses invade tight junctions formed by endothelial cells of the BBB [127,128]. During the Trojan horse strategy, a virus is engulfed by phagocytic host cells, such as neutrophils and macrophages. As lymphocytes, granulocytes, and monocytes all express ACE2, the SARS-CoV might be able to infect them [129-132], and it is likely that SARS-CoV-2 also may act in the same manner. Moreover, the COVID-19-related systemic inflammation would increase the BBB permeability, thus facilitating the invasion of the CNS by the infected immune cells $[133,134]$.

The fact that SARS-CoV-2 can infect macrophages, astroglia, and microglia makes it possible for the host's immune-mediated response to playing a substantial role. In some patients who died because of COVID-19, a multiple organ failure and a hyperinflammatory syndrome (the «cytokine storm») were hypothesized as possible underlying causes $[134,135]$. The cytokine storm associated with SARS-CoV-2 infection results in an increased secretion of pro-inflammatory cytokines and chemokines such as IL-6, TNF- $\alpha$, macrophage inflammatory protein 1-alpha, IP-10, and granulocyte-colony stimulating factor as well as C-reactive protein and ferritin. These observations indicate that upregulation of cytokines and systemic inflammation may be linked to disease severity. Cytokines and chemokines can bind to specific receptors on the cerebral microvascular endothelium leading to a BBB breakdown, neuroinflammation, and encephalitis. The loss of BBB integrity could loosen the tight junctions between the endothelial cells paving the way for paracellular traversal of SARS-CoV-2 into the CNS [126].

Due to the loss of BBB integrity, the endothelial cells, pericytes, and astrocytes compromise the ability to prevent immune cells from infiltrating the brain. Rather, immune cells are able to permeate the barrier and infiltrate the CNS, possibly attacking the brain cells, including the neurons. The resulting neuroinflammatory process may result in severe damage to brain function, as reported in $[128,136,137]$.

In total, SARS-CoV-2 via the ACE2 receptor on BMVEC cells can make entry into the brain, inducing a cytokine storm, endothelial inflammation, and alter the BBB integrity, which may facilitate COVID-19-related sleep disorders (Figure 4). Thus, anti-cytokinebased therapeutics or therapies that prevent the BBB damage may be effective in treating patients with COVID-19 associated sleep changes. Additional studies that investigate molecular mechanisms that underlie SARS- CoV-2 associated BBB injuries are warranted. 


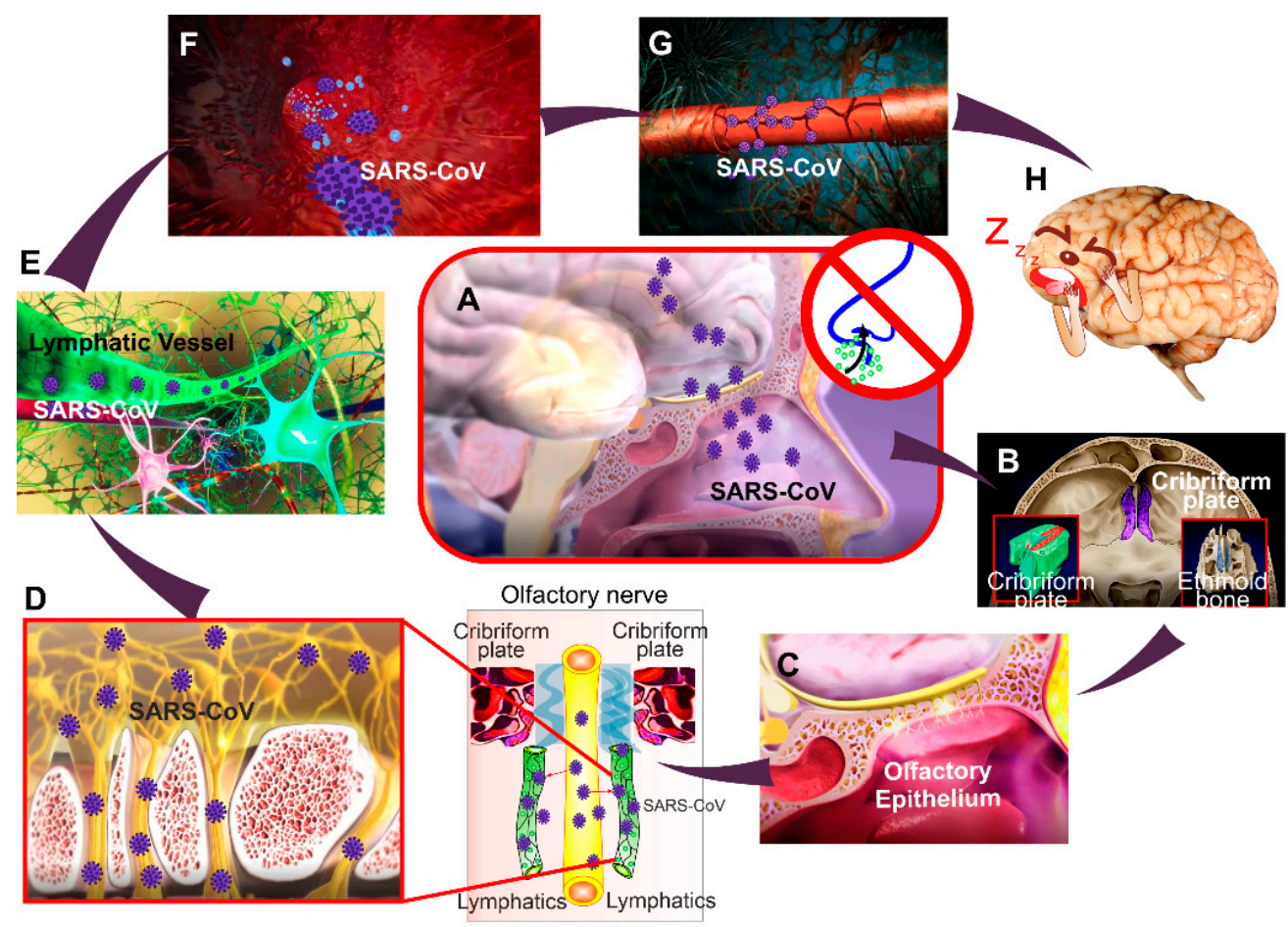

Figure 4. Brain mechanisms of COVID-19-sleep disorders: $(\mathrm{A}-\mathrm{C})$ The one hypothesis explains that the SARS-CoV-2 infiltrates the brain (A), possibly from the cribriform plate (B) and the olfactory epithelium (C). The cribriform plate (B) is a center of the lymphatic pathway of metabolic clearance and is a connective bridge between the cerebral spinal fluid and the cervical lymphatic system) [138-145]; $(\mathrm{D}, \mathrm{E})$ the virus can enter into the brain through the anatomical connection between the meningeal lymphatic vessels and the lymphatic vessels localized along the olfactory nerve [141]. The lymphatic window into the brain is considered in [146-148]; (F-H) The SARS-CoV-2 via the ACE2 receptor on the endothelial cells of the lymphatic vessels [149] can enter into the brain tissues inducing cytokine storm (F) and endothelial inflammation that alters the BBB integrity (G) facilitating COVID-19-related sleep disorders (H). SARS-CoV-2 also affects the olfactory centers (olfactory bulb and cortex), thereby reducing smell sensations [150-156].

\section{The Perspective Strategies for Prevention of COVID-19-Related BBB Disorders}

As discussed above, COVID-19-related sleep disorders are strongly associated with BBB leakage. Thus, the development of new technologies for the analysis of the BBB permeability can be a revolutionary step in the prevention of COVID-19-mediated BBB injuries. However, the monitoring of the degree and duration of the BBB permeability is a challenging problem $[157,158]$. Therefore, the interest in the development of methods for the assessment of BBB leakage in clinical practice has substantially increased over the past few years $[157,158]$. Computer tomography has been used to receive information about the BBB integrity $[159,160]$, but it has limited value. The dynamic contrast-enhanced magnetic resonance imaging (MRI) has proven valuable in the assessment of brain pathologies, which are accompanied by the BBB opening $[157,158]$. However, MRI is bulky and cannot be used at the bedside. Moreover, this procedure is expensive and is performed with contrast agents, which can be toxic $[161,162]$. This limits its continuous application and use, especially in children and patients with kidney pathology $[163,164]$. Therefore, the development of novel promising real-time, bedside, non-invasive, label-free, economically beneficial, and readily applicable methods is of the highest actual importance.

Here we discuss that the EEG analysis of sleep patterns can be a promising candidate for the BBB analysis and a breakthrough non-invasive technology for diagnosis of COVID19-caused BBB disruption. 
It is widely accepted that the main function of the BBB is the protection of the CNS from the penetration of microorganisms and toxins from the blood. However, the latest findings changed our understanding of the role of BBB in the keeping of CNS health. The BBB opening by music [165] or light [166] stimulates the lymphatic clearance of macromolecules from the brain. These new findings partly explain the fact that the BBB opening even without pharmacological therapy contributes to the clearance of amyloid-beta from the brain in patients with Alzheimer's disease and in mouse models of amyloidosis [167-170]. We do not know the mechanisms underlying the interrelation between sleep and the BBB opening. However, there is strong evidence that both sleep and the BBB are interlinked with activation of clearance of macromolecules and toxins from the brain that can be accompanied by similar changes in the neurological activity of the brain $[165,166,171-175]$.

There is the hypothesis that the sleep EEG slow wave activity (SWA) presents a new informative platform for extracting information about the BBB. Indeed, both sleep [171,172,175] and the BBB opening in humans and animals $[173,174,176]$ are characterized by special EEG patterns in SWA. The mechanisms of the EEG pattern changes during the BBB opening remain unknown. An increase in the BBB permeability can affect the EEG activity in different ways.

The BBB opening can directly affect the EEG dynamics. The signals generated by the $\mathrm{BBB}$ originate from a transendothelial resistance between blood and brain tissue. This voltage is a membrane potential of endothelial cells forming the BBB [177]. The BBB opening changes the voltage of endothelial cells, causing depolarization of their membranes $[178,179]$. These changes of cell potential cause up to $\mathrm{mV}$-level shifts in human scalp EEG [176,178,179]. Several experimental [180-182] and clinical [179,183,184] studies suggest that the BBB opening is accompanied by specific EEG changes, especially in SWA.

The BBB opening can influence the EEG behavior indirectly via astrocytes, which are essential for the BBB integrity and the EEG behavior $[185,186]$. The astrocytic mechanism of EEG changes may be related to the astrocytic-regulation of synaptic conductance [187-189], which is crucial for the electrical activity of cortical neurons.

Although it is too early to argue that EEG sleep patterns are a reliable marker of the $\mathrm{BBB}$ opening, it is not unreasonable to view that the EEG analysis of night brain activity can become a promising tool for effective extraction of information about the BBB permeability to SARS-CoV-2, cytokines and other substances. The development of new technologies of an EEG-based analysis of the BBB can be a revolutionary step in the prevention of COVID-19-sleep disorders and neurological diseases associated with BBB dysfunction. We have recently discussed the mechanisms of BBB-related EEG changes and the methods of modulations of these processes in our previous review [190].

\section{Conclusions}

To summarize, the COVID-19 pandemic is accompanied by the development of a growing number of COVID-19-related sleep disorders, known as the 'coronasomnia' phenomenon. The most dangerous consequence of sleep disturbances is the BBB disruption when the viruses, bacteria, and toxins can enter the brain and cause neuroinflammation. Therefore, the control of sleep hygiene and quality should be incorporated into routine therapy practice of COVID-19 patients. We highlight the pioneering direction in sleep research 2020-2021 and show that the EEG analysis of sleep patterns can be a revolutionary step in the control of COVID-19-caused BBB disruption. Furthermore, we discuss that SARS-CoV-2 can enter into the brain, directly altering the BBB integrity, which may facilitate COVID-19-related sleep disorders (Figure 4). The therapies that prevent the BBB damage may be effective in treating patients with COVID-19 and COVID-19-related sleep disorders. Additional studies that will be focused on the development of breakthrough technologies of an EEG-based analysis of BBB leakage as well as on the study of molecular mechanisms underlying SARS-CoV-2 associated sleep disorders and the BBB injuries are warranted. 
Author Contributions: Conceptualization, O.S.-G.; writing-original draft preparation, O.S.-G., A.M., V.V., M.K.; T.Y., D.Z., T.P., J.K., writing-review and editing, E.S. and V.A., prepared the figures and a design of manuscript; O.S.-G., T.Y., D.Z., T.P. and J.K.; project administration. All authors have read and agreed to the published version of the manuscript.

Funding: This work was supported by Grants of Russian Science Foundation: \#20-15-00090, \#18-7510033, RFBR grants \#19-515-55016, \#20-015-00308-a, RF Government Grant \#075-15-2019-1885, and National Natural Science Foundation of China: grants \#81961138015, \#61860206009.

Conflicts of Interest: The authors declare no conflict of interest.

\section{References}

1. Hui, D.S.; Azhar, E.I.; Madani, T.A.; Ntoumi, F.; Kock, R.; Dar, O.; Ippolito, G.; Mchugh, T.D.; Memish, Z.A.; Drosten, C.; et al. The continuing 2019-nCoV epidemic threat of novel coronaviruses to global health-The latest 2019 novel coronavirus outbreak in Wuhan, China. Int. J. Infec. Dis. 2020, 91, 264-266. [CrossRef] [PubMed]

2. Drosten, C.; Gunther, S.; Preiser, W.; Van der Werf, S.; Brodt, H.R.; Becker, S.; Rabenau, H.; Panning, M.; Kolesnikova, L.; Fouchier, R.A.; et al. Identification of a novel coronavirus in patients with severe acute respiratory syndrome. N. Engl. J. Med. 2003, 348, 1967-1976. [CrossRef]

3. Ksiazek, T.G.; Erdman, D.; Goldsmith, C.S.; Zaki, S.R.; Peret, T.; Emery, S.; Tong, S.; Urbani, C.; Comer, J.A.; Lim, W.; et al. A novel coronavirus associated with severe acute respiratory syndrome. N. Engl. J. Med. 2003, 348, 1953-1966. [CrossRef] [PubMed]

4. Peiris, J.S.; Lai, S.T.; Poon, L.L.; Guan, Y.; Yam, L.Y.; Lim, W.; Nicholls, J.; Yee, W.K.; Yan, W.W.; Cheung, M.T.; et al. Coronavirus as a possible cause of severe acute respiratory syndrome. Lancet 2003, 361, 1319-1325. [CrossRef]

5. Webster, R.G. Wet markets-A continuing source of severe acute respiratory syndrome and influenza? Lancet 2004, 363, 234-236. [CrossRef]

6. Woo, P.C.; Lau, S.K.; Yuen, K. Infectious diseases emerging from Chinese wet-markets: Zoonotic origins of severe respiratory viral infections. Curr. Opin. Infect. Dis. 2006, 19, 401-407. [CrossRef]

7. Sharifian-Dorche, M.; Huot, P.; Osherov, M.; Wen, D.; Saveriano, A.; Giacomini, P.; Antela, J.P.; Mowla, A. Neurological complications of coronavirus infection; a comparative review and lessons learned during the COVID-19 pandemic. J. Neurol. Sci. 2020, 417, 117085. [CrossRef]

8. Varatharaj, A.; Thomas, N.; Ellul, M.A.; Davies, N.W.S.; Pollak, T.A.; Tenorio, E.L.; Sultan, M.; Easton, A.; Breen, G.; Zandi, M.; et al. Neurological and neuropsychiatric complications of COVID-19 in 153 patients: A UK-wide surveillance study. Lancet Psychiatry 2020, 7, 875-882. [CrossRef]

9. Markuu, P. Sleep research in 2020: COVID-19-related sleep disorders. Lancet Neurol. 2021, 20, 15-17.

10. Huang, Y.; Zhao, N. Generalized anxiety disorder, depressive symptoms and sleep quality during COVID-19 outbreak in China: A web-based cross-sectional survey. Psychiatry Res. 2020, 288, 112954. [CrossRef]

11. Mazza, C.; Ricci, E.; Biondi, S.; Colasanti, M.; Ferracuti, S.; Napoli, C.; Roma, P. A nationwide survey of psychological distress among Italian people during the covid-19 pandemic: Immediate psychological responses and associated factors. Int. J. Environ. Res. Public Health 2020, 17, 3165. [CrossRef]

12. Zhang, C.; Yang, L.; Liu, S.; Ma, S.; Wang, Y.; Cai, Z.; Zhang, B. Survey of insomnia and related social psychological factors among medical staff involved in the 2019 novel Coronavirus disease outbreak. Front. Psychiatry 2020, 11, 306. [CrossRef] [PubMed]

13. Cellini, N.; Canale, N.; Mioni, G.; Costa, S. Changes in sleep pattern, sense of time and digital media use during COVID-19 lockdown in Italy. J. Sleep Res. 2020, 29, e13074. [CrossRef] [PubMed]

14. Rogers, J.P.; Chesney, E.; Oliver, D.; Pollak, T.A.; McGuire, P.; Fusar-Poli, P.; David, A.S. Psychiatric and neuropsychiatric presentations associated with severe coronavirus infections: A systematic review and meta-analysis with comparison to the COVID-19 pandemic. Lancet Psychiatry 2020, 7, 611-627. [CrossRef]

15. Partinen, M.; Kronholm, E. Epidemiology: Principles and application in sleep medicine. In Sleep Disorders Medicine: Basic Science, Technical Considerations and Clinical Aspects, 4th ed.; Chokroverty, S., Ed.; Springer: New York, NY, USA, 2017 ; pp. 485-521.

16. Belleville, G.; Ouellet, M.C.; Morin, C.M. Post-traumatic stress among evacuees from the 2016 fort mcmurray wildfires: Exploration of psychological and sleep symptoms three months after the evacuation. Int. J. Environ. Res. Public Health 2019, 16, 1604. [CrossRef]

17. Lavie, P. Sleep disturbances in the wake of traumatic events. N. Engl. J. Med. 2001, 345, 1825-1832. [CrossRef]

18. Partinen, M.; Bjorvatn, B.; Holzinger, B.; Chung, F.; Penzel, Y.; Espie, C.; Morin, C.; ICOSS-Collaboration Group. Sleep and circadian problems during the coronavirus disease 2019 (COVID-19) pandemic: The International COVID-19 Sleep Study (ICOSS). J. Sleep Res. 2020, 30, e13206. [CrossRef] [PubMed]

19. Altena, E.; Baglioni, C.; Espie, C.A.; Ellis, J.; Gavriloff, D.; Holzinger, B.; Schlarb, A.; Frase, L.; Jernelov, S.; Riemann, D. Dealing with sleep problems during home confinement due to the COVID-19 outbreak: Practical recommendations from a task force of the European CBT-I Academy. J. Sleep Res. 2020, 29, e13052. [CrossRef]

20. Casagrande, M.; Favieri, F.; Tambelli, R.; Forte, G. The enemy who sealed the world: Effects quarantine due to the COVID-19 on sleep quality, anxiety, and psychological distress in the Italian population. Sleep Med. 2020, 75, 12-20. [CrossRef]

21. Sher, L. COVID-19, anxiety, sleep disturbances and suicide. Sleep Med. 2020, 70, 124. [CrossRef] [PubMed]

22. Esme, S.; Bhvs, O.; Souza, J.C. Sleep and immunity in times of COVID-19. Rev. Assoc. Med. Bras. 2020, 66, $143-147$. 
23. Miller, M.A.; Cappuccio, F.P. A systematic review of COVID-19 and obstructive sleep apnoea. Sleep Med. Rev. 2021, 55, 101382. [CrossRef] [PubMed]

24. Wang, S.; Xie, L.; Xu, Y.; Yu, S.; Yao, B.; Xiang, D. Sleep disturbances among medical workers during the outbreak of COVID-2019. Occup Med. 2020, 70, 364-369. [CrossRef] [PubMed]

25. Marelli, S.; Castelnuovo, A.; Somma, A.; Castronovo, V.; Mombelli, S.; Bottoni, D.; Leitner, C.; Fossati, A.; Ferini-Strambi, L. Impact of COVID-19 lockdown on sleep quality in university students and administration staff. J. Neurol. 2021, 268, 8-15. [CrossRef]

26. Deng, J.; Zhou, F.; Hou, W.; Silver, Z.; Wong, C.Y.; Chang, O.; Huang, E.; Zuo, Q.K. The prevalence of depression, anxiety, and sleep disturbances in COVID-19 patients: A meta-analysis. Ann. N. Y. Acad. Sci. 2021, 1486, 90-111. [CrossRef]

27. Liu, Z.; Tang, H.; Jin, Q.; Wang, G.; Yang, Z.; Chen, H.; Yan, H.; Rao, W.; Owens, J. Sleep of preschoolers during the coronavirus disease 2019 (COVID-19) outbreak. J. Sleep Res. 2021, 30, e13142. [CrossRef]

28. Martínez-de-Quel, Ó.; Suárez-Iglesias, D.; López-Flores, M.; Pérez, C.A. Physical activity, dietary habits and sleep quality before and during COVID-19 lockdown: A longitudinal study. Appetite 2021, 158, 105019. [CrossRef]

29. Zhao, X.; Lan, M.; Li, H.; Yang, J. Perceived stress and sleep quality among the non-diseased general public in China during the 2019 coronavirus disease: A moderated mediation model. Sleep Med. 2020, 77, 339-345. [CrossRef]

30. Lucey, B.P. It's complicated: The relationship between sleep and Alzheimer's disease in humans. Neurol. Dis. 2020, $144,105031$.

31. Shokri-Kojori, E.; Wang, G.J.; Wiers, C.E.; Demiral, S.B.; Guo, M.; Kim, S.W.; Lindgren, E.; Ramirez, V.; Zehra, A.; Freeman, C.; et al. B-Amyloid accumulation in the human brain after one night of sleep deprivation. Proc. Natl. Acad. Sci. USA 2018, 115, 4483-4488. [CrossRef] [PubMed]

32. Bishir, M.; Bhat, A.; Essa, M.M.; Ekpo, O.; Ihunwo, A.O.; Veeraraghavan, V.P.; Mohan, S.K.; Mahalakshmi, A.M.; Ray, B.; Tuladhar, S.; et al. Sleep deprivation and neurological disorders. Hindawi BioMed Res. Int. 2020, 2020, 19.

33. Jahrami, H.; BaHammam, A.S.; Bragazzi, N.L.; Saif, Z.; Faris, M.; Vitiello, M.V. Sleep problems during the COVID-19 pandemic by population: A systematic review and meta-analysis. J. Clin. Sleep Med. 2021, 17, 299-313. [CrossRef]

34. Tony, A.A.; Tony, E.A.; Ali, S.B.; Ezzeldin, A.M.; Mahmoud, A.A. COVID-19-associated sleep disorders: A case report. Neurobiol. Sleep Circadian Rhythms 2020, 9, 100057. [CrossRef]

35. Hurtado-Alvarado, G.; Becerril-Villanueva, E.; Contis-Montes, O.A.; Domínguez-Salazar, E.; Salinas-Jazmín, N.; Pérez-Tapia, S.M.; Pavon, L.; Velázquez-Moctezuma, J.; Gómez-González, B. The yin/yang of inflammatory status: Blood-brain barrier regulation during sleep. Brain Behav. Immun. 2018, 69, 154-166. [CrossRef] [PubMed]

36. Pan, W.; Kastin, A.J. The blood-brain barrier: Regulatory roles in wakefulness and sleep. Neuroscientist 2017, $23,124-136$. [CrossRef]

37. Cuddapah, V.A.; Zhang, S.L.; Sehgal, A. Regulation of the blood-brain barrier by circadian rhythms and sleep. Trends Neurosci. 2019, 42, 500-510. [CrossRef] [PubMed]

38. Medina-Flores, F.; Hurtado-Alvarado, G.; Contis-Montes de Oca, A.; López-Cervantes, S.P.; Konigsberg, M.; Deli, M.A.; GómezGonzález, B. Sleep loss disrupts pericyte-brain endothelial cell interactions impairing blood-brain barrier function. Brain Behav. Immun. 2020, 89, 118-132. [CrossRef]

39. Hurtado-Alvarado, G.; Domínguez-Salazar, E.; Pavon, L.; Velázquez-Moctezuma, J.; Gómez-González, B. Blood-brain barier disruption induced by chronic sleep loss: Low-grade inflammation may be the link. J. Immunol. Res. 2016, 2016, 4576012. [CrossRef] [PubMed]

40. Sun, J.; Wu, J.; Hua, F.; Chen, Y.; Zhan, F.; Xu, G. Sleep deprivation induces cognitive impairment by increasing blood-brain barrier permeability via CD44. Front. Neurol. 2020, 11, 563916. [CrossRef] [PubMed]

41. Lim, D.C.; Pack, A.I. Obstructive sleep apnea and cognitive impairment: Addressing the blood-brain barrier. Sleep Med. Rev. 2014, 18, 35-48. [CrossRef]

42. Daulatzai, M.A. Cerebral hypoperfusion and glucose hypometabolism: Key pathophysiological modulators promote neurodegeneration, cognitive impairment, and Alzheimer's disease. J. Neurosci. Res. 2017, 95, 943-972. [CrossRef]

43. Voirin, A.C.; Celle, S.; Perek, N.; Roche, F. Sera of elderly obstructive sleep apnea patients alter blood-brain barrier integrity in vitro: A pilot study. Sci. Rep. 2020, 10, 11309. [CrossRef] [PubMed]

44. Hurtado-Alvarado, G.; Pavón, L.; Castillo-García, S.A.; Hernández, M.E.; Domínguez-Salazar, E.; Velázquez-Moctezuma, J.; Gómez-González, B. Sleep loss as a factor to induce cellular and molecular inflammatory variations. Clin. Dev. Immunol. 2013, 2013, 801341. [CrossRef] [PubMed]

45. Benedict, C.; Cedernaes, J.; Giedraitis, V.; Nilsson, E.K.; Hogenkamp, P.S.; Vågesjö, E.; Massena, S.; Pettersson, U.; Christoffersson, G.; Phillipson, M.; et al. Acute sleep deprivation increases serum levels of neuron-specific enolase (NSE) and S100 calcium binding protein B (S-100B) in healthy young men. Sleep 2014, 37, 195-198. [CrossRef] [PubMed]

46. Opp, M.R.; George, A.; Ringgold, K.M.; Hansen, K.M.; Bullock, K.M.; Banks, W.A. Sleep fragmentation and sepsis difeetially impact blood-brain barrier integrity and transport of tumor necrosis factorin aging. Brain Behav. Immun. 2015, 50, 259-265. [CrossRef]

47. Krueger, J.M.; Majde, J.A. Humoral links between sleep and the immune system: Research issues. Ann. N. Y. Acad. Sci. 2003, 992, 9-20. [CrossRef] [PubMed]

48. Straub, R.; Männel, D. How the immune system puts the brain to sleep. Nat. Med. 1999, 5, 877-879. [CrossRef]

49. Hirotsu, C.; Rydlewski, M.; Araújo, M.S.; Tufik, S.; Andersen, M.L. Sleep loss and cytokines levels in an experimental model of psoriasis. PLoS ONE 2012, 7, e51183. [CrossRef] 
50. He, J.; Hsuchou, H.; He, Y.; Kastin, A.J.; Wang, Y.; Pan, W. Sleep restriction impairs blood-brain barrier function. J. Neurosci. 2014, 34, 14697-14706. [CrossRef]

51. Ibrahim, L.; Duncan, W.; Luckenbaugh, D.A.; Yuan, P.; Machado-Vieira, R.; Zarate, C.A., Jr. Rapid antidepressant changes with sleep deprivation in major depressive disorder are associated with changes in vascular endothelial growth factor (VEGF): A pilot study. Brain Res. Bull. 2011, 86, 129-133. [CrossRef]

52. Li, K.; Wei, P.; Qin, Y.; Wei, Y. Is C-reactive protein a marker of obstructive sleep apnea? Medicine 2017, 96, e6850. [CrossRef] [PubMed]

53. Gabryelska, A.; Szmyd, B.; Panek, M.; Szemraj, J.; Kuna, P.; Białasiewicz, P. Serum hypoxia-inducible factor-1 $\alpha$ protein level as a diagnostic marker of obstructive sleep apnea. Pol. Arch. Intern. Med. 2020, 130, 158-160. [CrossRef]

54. Hurtado-Alvarado, G.; Domínguez-Salazar, E.; Velázquez-Moctezuma, J.; Gómez-González, B. A2A adenosine receptor antagonism reverts the blood-brain barrier dysfunction induced by sleep restriction. PLoS ONE 2016, 11, e0167236. [CrossRef]

55. Gomez-Gonzalez, B.; Hurtado-Alvarado, G.; Esqueda-Leon, E.; Santana-Miranda, R.; Rojas-Zamorano, J.A.; VelazquezMoctezuma, J. REM Sleep Loss and Recovery Regulates Blood-Brain Barrier Function. Curr. Neurovasc. Res. 2013, 10, $197-207$. [CrossRef] [PubMed]

56. Hurtado-Alvarado, G.; Velázquez-Moctezuma, J.; Gómez-González, B. Chronic sleep restriction disrupts interendothelial tight junctions in the hippocampus and increases blood-brain barrier permeability. J. Microsc. 2017, 268, 28-31. [CrossRef] [PubMed]

57. Saunders, N.R.; Dziegielewska, K.M.; Mollgard, K.; Habgood, M.D. Markers for blood-brain barrier integrity: How apprpriate is Evans blue in the twenty-first century and what are the alternatives. Front. Neurosci. 2015, 9, 385. [CrossRef]

58. Chennaoui, M.; Sauvet, F.; Drogou, C.; Van Beers, P.; Langrume, C.; Guillard, M.; Gourby, B.; Bourrilhon, C.; Florence, G.; Gomez-Merino, D. Effect of one night of sleep loss on changes in tumor necrosis factor alpha (TNF- $\alpha$ ) levels in healthy men. Cytokine 2011, 56, 318-324. [CrossRef]

59. Zielinski, M.R.; Kim, Y.; Karpova, S.A.; McCarley, R.W.; Strecker, R.E.; Gerashchenko, D. Chronic sleep restriction elevates brain interleukin-1 beta and tumor necrosis factor-alpha and attenuates brain-derived neurotrophic factor expression. Neurosci. Lett. 2014, 580, 27-31. [CrossRef]

60. Vgontzas, A.N.; Zoumakis, M.; Papanicolaou, D.A.; Bixler, E.; Prolo, P.; Lin, H.-M.; Vela-Bueno, A.; Kales, A.; Chrousos, G. Chronic insomnia is associated with a shift of interleukin- 6 and tumor necrosis factor secretion from nighttime to daytime. Metabolism 2002, 51, 887-892. [CrossRef]

61. Van Leeuwen, W.M.A.M.; Karisola, L.P.; Karisola, P.; Lindholm, H.; Luukkonen, R.; Sallinen, M.; Alenius, H. Sleep restriction increases the risk of developing cardiovascular diseases by augmenting proinflammatory responses through IL-17 and CRP. PLoS ONE 2009, 4, e4589. [CrossRef]

62. Okun, M.L.; Coussons-Read, M.; Hall, M. Disturbed sleep is associated with increased C-reactive protein in young women. Brain Behav. Immun. 2009, 23, 351-354. [CrossRef]

63. Carver, K.A.; Lourim, D.; Tryba, A.K.; Harder, D.R. Rhythmic expression of cytochrome P450 epoxygenases CYP4×1 and CYP2c11 in the rat brain and vasculature. Am. J. Physiol. Cell Physiol. 2014, 307, 989. [CrossRef] [PubMed]

64. Gao, Y.; Meng, D.; Sun, N.; Zhu, Z.; Zhao, R.; Lu, C.; Chen, S.; Hua, L.; Qian, R. Clock upregulates intercellular adhesion molecule-1 expression and promotes mononuclear cells adhesion to endothelial cells. Biochem. Biophys. Res. Commun. 2014, 443, 586-591. [CrossRef] [PubMed]

65. Mohawk, J.A.; Green, C.; Takahashi, J. Central and peripheral circadian clocks in mammals. Annu. Rev. Neurosci. 2012, 35, 445-462. [CrossRef]

66. Davidson, A.J.; London, B.; Block, G.; Menaker, M. Cardiovascular tissues contain independent circadian clocks. Clin. Exp. Hypertens. 2005, 27, 307-311. [CrossRef] [PubMed]

67. Durgan, D.J.; Grossland, R.; Bryan, J. The rat cerebral vasculature exhibits time-of-day-dependent oscillations in circadian clock genes and vascular function that are attenuated following obstructive sleep apnea. J. Cereb. Blood Flow Metab. 2017, 37, 2806-2819. [CrossRef]

68. Shintaro, H.; Mona, U.; Kumiko, T.; Rie, H.; Yuki, T.; Masaaki, M.; Toshio, H. How COVID-19 induces cytokine storm with high mortality. Inflamm. Regen. 2020, 40, 37.

69. Tay, M.Z.; Poh, C.M.; Renia, L.; MacAry, P.A.; Ng, L.F.P. The trinity of COVID-19: Immunity, inflammation and intervention. Nat. Rev. Immunol. 2020, 20, 363-374. [CrossRef]

70. Chen, N.; Zhou, M.; Dong, X.; Qu, J.; Gong, F.; Han, Y.; Qui, P.; Wang, J.; Liu, J.; Wei, Y.; et al. Epidemiological and clinical characteristics of 99 cases of 2019 novel coronavirus pneumonia in Wuhan, China: A descriptive study. Lancet 2020, 395, 507-513. [CrossRef]

71. Coronaviridae Study Group of the International Committee on Taxonomy of V. The species severe acute respiratory syndromerelated coronavirus: Classifying 2019-nCoV and naming it SARS-CoV-2. Nat. Microbiol. 2020, 5, 536-544. [CrossRef]

72. Huang, C.; Wang, Y.; Li, X.; Ren, L.; Zhao, J.; Hu, Y.; Zhang, L.; Fan, G.; Xu, J.; Gu, X.; et al. Clinical features of patients infected with 2019 novel coronavirus in Wuhan, China. Lancet 2020, 395, 497-506. [CrossRef]

73. Zhou, F.; Yu, T.; Du, R.; Fan, G.; Liu, Y.; Liu, Z.; Xiang, J.; Wang, J.; Song, B.; Gi, X.; et al. Clinical course and risk factors for mortality of adult inpatients with COVID-19 in Wuhan, China: A retrospective cohort study. Lancet 2020, 395, 1054-1062. [CrossRef] 
74. Liu, B.; Li, M.; Zhou, Z.; Guan, X.; Xiang, Y. Can we use interleukin-6 (IL-6) blockade for coronavirus disease 2019 (COVID-19)induced cytokine release syndrome (CRS)? J. Autoimmun. 2020, 111, 102452. [CrossRef]

75. Hirano, T.; Murakami, M. COVID-19: A new virus, but a familiar receptor and cytokine release syndrome. Immunity 2020, 52, 731-733. [CrossRef]

76. Mahmudpour, M.; Roozbeh, J.; Keshavarz, M.; Farrokhi, S.; Nabipour, I. COVID-19 cytokine storm: The anger of inflammation Cytokine 2020, 133, 155151. [CrossRef] [PubMed]

77. McGonagle, D.; Sharif, K.; O'Regan, A.; Bridgewood, C. The role of cytokines including interleukin-6 in COVID-19 induced pneumonia and macrophage activation syndrome-like disease. Autoimmun. Rev. 2020, 9, 102537. [CrossRef] [PubMed]

78. Pan, W.; Cornélissen, G.; Halberg, F.; Kastin, A.J. Selected contribution: Circadian rhythm of tumor necrosis factor-alpha uptake into mouse spinal cord. J. Appl. Physiol. 2002, 92, 62. [CrossRef] [PubMed]

79. Pan, W.; Kastin, A.J. TNFalpha transport across the blood-brain barrier is abolished in receptor knockout mice. Exp. Neurol. 2002, 174, 193-200. [CrossRef] [PubMed]

80. Agorastos, A.; Hauger, R.L.; Barkauskas, D.A.; Moeller-Bertram, T.; Clopton, P.L.; Haji, U.; Lohr, J.B.; Geracioti, T.D., Jr.; Patel, P.M.; Chrousos, G.P.; et al. Circadian rhythmicity, variability and correlation of interleukin-6 levels in plasma and cerebrospinal fluid of healthy men. Psychoneuroendocrinology 2014, 44, 71-82. [CrossRef]

81. Banks, W.A.; Kastin, A.J.; Gutierrez, E.G. Penetration of interleukin-6 across the murine blood-brain barrier. Neurosci. Lett. 1994, 179, 53-56. [CrossRef]

82. Banks, W.A. Diurnal uptake of circulating interleukin-1alpha by brain, spinal cord, testis and muscle. Neuroimmunomodulation 1998, 5, 36-41. [CrossRef]

83. Choy, E.H.; De Benedetti, F.; Takeuchi, T.; Hashizume, M.; John, M.R.; Kishimoto, T. Translating IL-6 biology into effective treatments. Nat. Rev. Rheumatol. 2020, 16, 335-345. [CrossRef]

84. Maric, J.; Ravindran, A.; Mazzurana, L.; Van Acker, A.; Rao, A.; Kokkinou, E.; Ekoff, M.; Thomas, D.; Fauland, A.; Nilsson, G.; et al. Cytokine-induced endogenous production of prostaglandin D2 is essential for human group 2 innate lymphoid cell activation. J. Allergy Clin. Immunol. 2019, 143, 2202-2214. [CrossRef]

85. Oyesola, O.O.; Duque, C.; Huang, L.C.; Larson, E.M.; Früh, S.P.; Webb, L.M.; Peng, S.A.; Tait Wojno, E.D. The Prostaglandin D2 Receptor CRTH2 Promotes IL-33-Induced ILC2 Accumulation in the Lung. J. Immunol. 2020, 204, 1001-1011. [CrossRef] [PubMed]

86. Pandey, H.P.; Ram, A.; Matsumura, H.; Hayaishi, O. Concentration of prostaglandin D2 in cerebrospinal fluid exhibits a circadian alteration in conscious rats. Biochem. Mol. Biol. Int. 1997, 37, 431-437.

87. Ram, A.; Pandey, H.P.; Matsumura, H.; Kasahara-Orita, K.; Nakajima, T.; Takahata, R.; Satoh, S.; Terao, A.; Hayaishi, O. CSF levels of prostaglandins, especially the level of prostaglandin D2, are correlated with increasing propensity towards sleep in rats. Brain Res. 1997, 751, 81-89. [CrossRef]

88. McNamee, E.N.; Ryan, K.M.; Griffin, E.W.; González-Reyes, R.E.; Ryan, K.J.; Harkin, A.; Connor, T.J. Noradrenaline acting at central beta-adrenoceptors induces interleukin-10 and suppressor of cytokine signaling-3 expression in rat brain: Implications for neurodegeneration. Brain Behav. Immun. 2010, 24, 660-671. [CrossRef]

89. O'Neill, E.; Harkin, A. Targeting the noradrenergic system for anti-inflammatory and neuroprotective effects: Implications for Parkinson's disease. Neural Regen. Res. 2018, 13, 1332-1337. [PubMed]

90. Staedtke, V.; Bai, R.Y.; Kim, K.; Darvas, M.; Davilo, M.L.; Riggins, G.J.; Rothman, P.B.; Papadopoulos, N.; Kinzler, K.W.; Vogelstein, B.; et al. Disruption of a self-amplifying catecholamine loop reduces cytokine release syndrome. Nature 2018, 564, $273-277$. [CrossRef]

91. Pan, L.; Dong, L. Epinephrine use in COVID-19: Friend or foe? Eur. J. Hosp. Pharm. 2021, 28 , e1.

92. Wood, J.H.; Ziegler, M.C.; Lake, C.R.; Ebert, M.H. Circadian rhythm in cerebrospinal fluid noradrenaline of man and monkey. Nature 1976, 264, 656-658. [CrossRef] [PubMed]

93. Manshardt, J.; Wurtman, R. Daily rhythm in the noradrenaline content of rat hypothalamus. Nature 1968, 217, 574-575. [CrossRef] [PubMed]

94. Reis, D.J.; Wurtman, R.J. Diurnal changes in brain noradrenalin. Life Sci. 1968, 7, 91-98. [CrossRef]

95. Reis, D.J.; Weinbren, M.; Corvelli, A. A circadian rhythm of norepinephrine regionally in cat brain: Its relationship to environmental lighting and to regional diurnal variations in brain serotonin. J. Pharmacol. Exp. Ther. 1968, 164, $135-145$.

96. Freidman, A.H.; Walker, C.A. Circadian rhythms in rat mid-brain and caudate nucleus biogenic amine levels. J. Physiol. 1968, 197, 77-85. [CrossRef]

97. Lew, G.M.; Quay, W.B. The mechanism of circadian rhythms in brain and organ contents of norepinephrine: Circadian changes in the effects of methyltyrosine and 6-hydroxydopamine. Comp. Gen. Pharmacol. 1973, 4, 375-381. [CrossRef]

98. Eleftheriou, B.S. Circadian rhythm in blood and brain biogenic amines and other biochemical changes in rabbits. Brain Res. 1974, 75, 145-152. [CrossRef]

99. Mitchell, H.A.; Weinshenker, D. Good night and good luck: Norepinephrine in sleep pharmacology. Biochem. Pharm. 2010, 79, 801-809. [CrossRef]

100. Aston-Jones, G.; Bloom, F.E. Activity of norepinephrine-containing locus coeruleus neurons in behaving rats anticipates fluctuations in the sleep-waking cycle. J. Neurosci. 1981, 1, 876-886. [CrossRef] 
101. Shimba, A.; Ikuta, K. Glucocorticoids regulate circadian rhythm of innate and adaptive immunity. Front. Immunol. $2020,11,2143$. [CrossRef]

102. Szmyd, B.; Rogut, M.; Białasiewicz, P.; Gabryelska, A. The impact of glucocorticoids and statins on sleep quality. Sleep Med. Rev. 2021, 55, 101380. [CrossRef]

103. Daneman, R.; Prat, A. The blood-brain barrier. Cold Spring Harb Perspect. Biol. 2015, 7, a020412. [CrossRef]

104. Abbott, J.; Patabendige, A.; Dolman, D.; Yusof, S.; Begley, D. Structure and function of the blood-brain barrier. Neurobiol. Dis. 2010, 37, 13-25. [CrossRef] [PubMed]

105. King, M.; Su, W.; Chang, A.; Zuckerman, A.; Pasternak, G.W. Transport of opioids from the brain to the periphery by Pglycoprotein: Peripheral actions of central drugs. Nat. Neurosci. 2001, 4, 268-274. [CrossRef]

106. Loscher, W.; Potschka, H. Blood-brain barrier active efflux transporters: ATP-binding cassette gene family. NeuroRx 2005, 2, 86-98. [CrossRef]

107. Kervezee, L.; Hartman, R.; van den Berg, D.J.; Shimizu, S.; Emoto-Yamamoto, Y.; Meijer, J.H.; de Lange, E.C. Diurnal variation in P-glycoprotein-mediated transport and cerebrospinal fluid turnover in the brain. AAPS J. 2014, 16, 1029-1037. [CrossRef] [PubMed]

108. Zhang, S.L.; Lahens, N.F.; Yue, Z.; Arnold, D.M.; Pakstis, P.P.; Schwarz, J.E.; Sehgal, A. A circadian clock in the blood-brain barrier regulates xenobiotic efflux. Cell 2018, 173, 130-139.e10. [CrossRef]

109. Hindle, S.J.; Munji, R.N.; Dolghih, E.; Gaskins, G.; Orng, S.; Ishimoto, H.; Soung, A.; DeSalvo, M.; Kitamoto, T.; Keiser, M.J.; et al. Evolutionarily Conserved roles for blood-brain barrier xenobiotic transporters in endogenous steroid partitioning and behavior. Cell Rep. 2017, 21, 1304-1316. [CrossRef]

110. Baig, A.M. Neurological manifestations in COVID-19 caused by SARS-CoV-2. CNS Neurosci. 2020, 26, 499-501. [CrossRef] [PubMed]

111. Hoffmann, M.; Kleine-Weber, H.; Schroeder, S.; Krüger, N.; Herrler, T.; Erichsen, S.; Schiergens, T.S.; Herrler, G.; Wu, N.-H.; Nitsche, A.; et al. SARS-CoV-2 cell entry depends on ACE2 and TMPRSS2 and is blocked by a clinically proven protease inhibitor. Cell 2020, 181, 1-16. [CrossRef] [PubMed]

112. Walls, A.C.; Park, Y.-J.; Tortorici, M.A.; Wall, A.; McGuire, A.T.; Veesler, D. Structure, function, and antigenicity of the SARS-CoV-2 spike glycoprotein. Cell 2020, 181, 281-292. [CrossRef]

113. Hoffmann, M.; Kleine-Weber, H.; Pöhlmann, S. A multibasic cleavage site in the Spike protein of SARS-CoV-2 is essential for infection of human lung cells. Mol. Cell 2020, 78, 1-6. [CrossRef] [PubMed]

114. Mayi, B.S.; Leibowitz, J.A.; Woods, A.T.; Ammon, K.A.; Liu, A.E.; Raja, A. The role of Neuropilin-1 in COVID-19. PLoS Pathog. 2021, 17, e1009153. [CrossRef] [PubMed]

115. Cantuti-Castelvetri, L.; Ojha, R.; Pedro, L.D.; Djannatian, M.; Franz, J.; Kuivanen, S.; van der Meer, F.; Kallio, K.; Kaya, T.; Anastasina, M.; et al. Neuropilin-1 facilitates SARS-CoV-2 cell entry and infectivity. Science 2020, 370, 856-860. [CrossRef] [PubMed]

116. Hamming, W.T.; Bulthuis, M.L.C.; Lely, A.T.; Navis, G.J.; Goor, H. Tissue distribution of ACE2 protein, the functional receptor for SARS coronavirus. A first step in understanding SARS pathogenesis. J. Pathol. 2004, 203, 631-637. [CrossRef] [PubMed]

117. Wang, Y.; Cao, Y.; Mangalam, A.K.; Guo, Y.; LaFrance-Corey, R.G.; Gamez, J.D.; Atanga, P.A.; Clarkson, B.D.; Zhang, Y.; Wang, E.; et al. Neuropilin-1 modulates interferon-gamma-stimulated signaling in brain microvascular endothelial cells. J. Cell Sci. 2016, 129, 3911-3921.

118. Paniz-Mondolfi, A.; Bryce, C.; Grimes, Z.; Gordon, R.E.; Reidy, J.; Lednicky, J.; Sordillo, E.M.; Fowkes, M. Central nervous system involvement by severe acute respiratory syndrome coronavirus-2 (SARS-CoV-2). J. Med. Virol. 2020, 92, 699-702. [CrossRef] [PubMed]

119. Burks, S.M.; Rosas-Hernandez, H.; Alenjandro Ramirez-Lee, M.; Cuevas, E.; Talpos, J.C. Can SARS-CoV-2 infect the central nervous system via the olfactory bulb or the blood-brain barrier? Brain Behav. Immun. 2021, 95, 7-14. [CrossRef]

120. Bleau, C.; Filliol, A.; Samson, M.; Lamontagne, L.; Perlman, S. Brain invasion by mouse hepatitis virus depends on impairment of tight junctions and beta interferon production in brain microvascular endothelial cells. J. Virol. 2015, 89, 9896-9908. [CrossRef]

121. Cabirac, G.F.; Soike, K.F.; Butunoi, C.; Hoel, K.; Johnson, S.; Cai, G.Y.; Murray, R.S. Coronavirus JHM OMP1 pathogenesis in owl monkey CNS and coronavirus infection of owl monkey CNS via peripheral routes. Adv. Exp. Med. Biol. 1993, 342, 347-352.

122. Cabirac, G.F.; Soike, K.F.; Zhang, J.Y.; Hoel, K.; Butunoi, C.; Cai, G.Y.; Johnson, S.; Murray, R.S. Entry of coronavirus into primate CNS following peripheral infection. Microb. Pathog. 1994, 16, 349-357. [CrossRef]

123. Cabirac, G.F.; Murray, R.S.; McLaughlin, L.B.; Skolnick, D.M.; Hogue, B.; Dorovini-Zis, K.; Didier, P.J. In vitro interaction of coronaviruses with primate and human brain microvascular endothelial cells. Adv. Exp. Med. Biol. 1995, 380, 79-88.

124. Buzhdygan, T.P.; DeOre, B.J.; Baldwin-Leclair, A.; Bullock, T.A.; McGary, H.M.; Khan, J.A.; Razmpour, R.; Hale, J.F.; Galie, P.A.; Potula, R.; et al. The SARS-CoV-2 spike protein alters barrier function in 2D static and 3D microfluidic in-vitro models of the human blood-brain barrier. Neurobiol. Dis. 2020, 146, 105131. [CrossRef]

125. Bellon, M.; Schweblin, C.; Lambeng, N.; Cherpillod, P.; Vazquez, J.; Lalive, P.H.; Schibler, M.; Deffert, C. Cerebrospinal fluid features in SARS-CoV-2 RT-PCR positive patients. Clin. Infect. Dis. 2020, ciaa1165. [CrossRef]

126. Alam, S.B.; Willows, S.; Kulka, M.; Sandhu, J.K. Severe acute respiratory syndrome coronavirus 2 may be an underappreciated pathogen of the central nervous system. Eur. J. Neurol. 2020, 27, 2348-2360. [CrossRef] 
127. Robinson, C.P.; Busl, K.M. Neurologic manifestations of severe respiratory viral contagions. Crit. Care Explor. 2020,2 , e0107. [CrossRef]

128. Achar, A.; Ghosh, C. COVID-19-associated neurological disorders: The potential route of CNS invasion and blood-brain barrier relevance. Cells 2020, 9, 2360. [CrossRef] [PubMed]

129. Gu, J.; Gong, E.; Zhang, B.; Zheng, J.; Gao, Z.; Zhong, Y.; Zou, W.; Zhan, J.; Wang, S.; Xie, Z.; et al. Multiple organ infection and the pathogenesis of SARS. J. Exp. Med. 2005, 202, 415-424. [CrossRef] [PubMed]

130. Nicholls, J.M.; Butany, J.; Poon, L.L.M.; Chan, K.H.; Beh, S.L.; Poutanen, S.; Peiris, J.S.M.; Wong, M. Time course and cellular localization of SARS-CoV nucleoprotein and RNA in lungs from fatal cases of SARS. PLoS Med. 2006, 3, e27. [CrossRef]

131. Spiegel, M.; Schneider, K.; Weber, F.; Weidmann, M.; Hufert, F.T. Interaction of severe acute respiratory syndrome-associated coronavirus with dendritic cells. J. Gen. Virol. 2006, 87, 1953-1960. [CrossRef] [PubMed]

132. Trojanowicz, B.; Ulrich, C.; Kohler, F.; Bode, V.; Seibert, E.; Fiedler, R.; Girndt, M. Monocytic angiotensin-converting enzyme 2 relates to atherosclerosis in patients with chronic kidney disease. Nephrol. Dial. Transpl. 2017, 32, 287-298. [CrossRef]

133. Sankowski, R.; Mader, S.; Valdés-Ferrer, S.I. Systemic Inflammation and the Brain: Novel Roles of Genetic, Molecular, and Environmental Cues as Drivers of Neurodegeneration. Front. Cell. Neurosci. 2015, 9, 28. [CrossRef] [PubMed]

134. Pennisi, M.; Lanza, G.; Falzone, L.; Fisicaro, F.; Ferri, R.; Bella, R. SARS-CoV-2 and the nervous system: From clinical features to molecular mechanisms. Int. J. Mol. Sci. 2020, 21, 5475. [CrossRef]

135. Mehta, P.; McAuley, D.F.; Brown, M.; Sanchez, E.; Tattersall, R.S.; Manson, J.J.; HLH Across Speciality Collaboration, UK. COVID-19: Consider cytokine storm syndromes and immunosuppression. Lancet 2020, 395, 1033-1034. [CrossRef]

136. Steardo, L.; Steardo, L., Jr.; Zorec, R.; Verkhratsky, A. Neuroinfection may contribute to pathophysiology and clinical manifestations of COVID-19. Acta Physiol. 2020, 229, e13473. [CrossRef]

137. Varatharaj, A.; Galea, I. The blood-brain barrier in systemic inflammation. Brain Behav. Immun. 2017, 60, 1-12. [CrossRef]

138. Koh, L.; Zakharov, A.; Johnston, M. Integration of the subarachnoid space and lymphatics: Is it time to embrace a new concept of cerebrospinal fluid absorption? Cereb. Fluid Res. 2005, 2, 6. [CrossRef]

139. Cserr, H.F.; Knopf, P.M. Cervical lymphatics, the blood-brain barrier and the immunoreactivity of the brain: A new view. Immunol. Today 1992, 13, 507-512. [CrossRef]

140. Bradbury, M. Lymphatics and the central nervous system. Trends Neurosci. 1981, 4, 100-101. [CrossRef]

141. Ma, Q.; Ries, M.; Decker, Y.; Muller, A.; Riner, C.; Bucker, A.B.; Fassbender, K.; Detmar, M.; Proulx, S.T. Rapid lymphatic efflux limits cerebrospinal fluid flow to the brain. Acta Neuropathol. 2019, 137, 151-165. [CrossRef] [PubMed]

142. Weller, R.O.; Kida, S.; Zhang, E.T. Pathways of fluid drainage from the brain-morphological aspects and immunological significance in rat and man. Brain Pathol. 1992, 2, 277-284. [CrossRef]

143. Kida, S.; Pantazis, A.; Weller, R. CSF drains directly from the subarachnoid space into nasal lymphatics in the rat. anatomy, histology and immunological significance. Neuropathol. Appl. Neurobiol. 1993, 19, 480-488. [CrossRef]

144. Johnston, M.; Zakharov, A.; Papaiconomou, C.; Salmasi, G.; Armstrong, D. Evidence of connections between cerebrospinal fluid and nasal lymphatic vessels in humans, non-human primates and other mammalian species. Cereb. Fluid Res. 2004, 1, 2. [CrossRef]

145. De Leon, M.J.; Li, Y.; Okamura, N.; Tsui, W.H.; Saint-Louis, L.A.; Glodzik, L.; Osorio, R.S.; Fortea, J.; Butler, T.; Pirraglia, E.; et al. Cerebrospinal fluid clearance in Alzheimer's disease measured with dynamic pet. J. Nucl. Med. 2017, 58, 1471-1476. [CrossRef]

146. Song, J.; Lee, S.-S.; Lim, S.; Yeo, S. Mechanism of the neuroprotective effect of injecting brain cells on st36 in an animal model of Parkinson's disease. Neurosci. Lett. 2020, 717, 34698. [CrossRef]

147. Zhao, P.; Le, Z.; Liu, L.; Chen, Y. Therapeutic delivery to the brain via the lymphatic vasculature. Nano Lett. 2020, 20, 5415-5420. [CrossRef] [PubMed]

148. Semyachkina-Glushkovskaya, O. Biophotonic strategies of measurement and stimulation of the cranial and the extracranial lymphatic drainage function. IEEE J. Sel. Top. Quantum Electron. 2021, 27, 1-13. [CrossRef]

149. Li, J.; Gao, J.; Xu, Y.P.; Zhou, T.L.; Jin, Y.Y.; Lou, J.N. Expression of severe acute respiratory syndrome coronavirus receptors, ACE2 and CD209L in different organ derived microvascular endothelial cells. Zhonghua Yi Xue Za Zhi 2007, 87, 833-837. (In Chinese) [PubMed]

150. Butowt, R.; Christopher, S.B. Anosmia in COVID-19: Underlying mechanisms and assessment of an olfactory route to brain infection. Neuroscientist 2020, 11, 1073858420956905. [CrossRef]

151. Aragão, M.D.F.V.V.; Leal, M.C.; Cartaxo Filho, O.Q.; Fonseca, T.M.; Valença, M.M. Anosmia in covid-19 associated with injury to the olfactory bulbs evident on mri. Am. J. Neuroradiol. 2020, 41, 1703-1706. [CrossRef]

152. Baig, A.M.; Khaleeq, A.; Ali, U.; Syeda, H. Evidence of the covid-19 virus targeting the CNS: Tissue distribution, host-virus interaction, and proposed neurotropic mechanisms. ACS Chem. Neurosci. 2020, 11, 995-998. [CrossRef]

153. Briguglio, M.; Bona, A.; Porta, M.; Dell'Osso, B.; Pregliasco, F.E.; Banfi, G. Disentangling the hypothesis of host dysosmia and sars-cov 2: The bait symptom that hides neglected neurophysiological routes. Front. Physiol. 2020, 11, 671. [CrossRef] [PubMed]

154. Gilani, S.; Roditi, R.; Naraghi, M. Covid-19 and anosmia in tehran, iran. Med. Hypotheses 2020, 141, 109757. [CrossRef] [PubMed]

155. Karimi-Galougahi, M.; Yousefi-Koma, A.; Bakhshayeshkaram, M.; Raad, N.; Haseli, S. 18fdg pet/ct scan reveals hypoactive or bitofrontal cortex in anosmia of covid-19. Acad. Radiol. 2020, 27, 1042-1043. [CrossRef] [PubMed] 
156. Beeraka, N.M.; Sadhu, S.P.; Madhunapantula, S.V.; Pragada, R.R.; Svistunov, A.A.; Nikolenko, V.N.; Mikhaleva, L.M.; Aliev, G. Strategies for targeting sars cov-2: Small molecule inhibitors-The current status. Front. Immunol. 2020, 11, 552925. [CrossRef] [PubMed]

157. Chassidim, Y.; Veksler, R.; Lublinsky, S.; Pell, G.; Friedman, A.; Shelef, I. Quantitative imaging assessment of blood-brain barrier permeability in humans. Fluids Barriers CNS 2013, 10, 9. [CrossRef]

158. Heye, A.K.; Culling, R.D.; Valdés Hernández, M.C.; Thrippleton, M.J.; Wardlaw, J.M. Assessment of blood-brain barrier disruption using dynamic contrast-enhanced MRI. A systematic review. NeuroImage Clin. 2014, 6, 262-274. [CrossRef]

159. Neuwelt, E.A.; Maravilla, K.; Frenkel, E.; Ripaport, S.; HilL, S.; Barnett, P. Osmotic blood-brain barrier disruption. Computerized tomographic monitoring of chemotherapeutic agent delivery. J. Clin. Investig. 1979, 64, 684-688. [CrossRef]

160. Roman-Goldstein, S.; Clunie, D.; Stevens, D.; Hogan, R.; Monard, J.; Ramsay, F.; Neuwelt, E. Osmotic blood-brain barrier disruption: CT and radionuclide imaging. AJNR Am. J. Neuroradiol. 1994, 15, 581-590.

161. Rogosnitzky, M.; Branch, S. Gadolinium-based contrast agent toxicity: A review of known and proposed mechanisms. Biometals 2016, 29, 365-376. [CrossRef]

162. Kaller, M.O.; An, J.; Contrast Agent Toxicity. StatPearls [Internet]; StatPearls Publishing: Treasure Island, FL, USA, 2020. Available online: https:/ / www.ncbi.nlm.nih.gov/books/NBK537159/ (accessed on 10 May 2021).

163. Elbeshlawi, I.; AbdelBaki, M.S. Safety of gadolinium administration in children. Pediatr. Neurol. 2018, 86, 27-32. [CrossRef]

164. Perazella, M.A. Gadolinium-contrast toxicity in patients with kidney disease: Nephrotoxicity and nephrogenic systemic fibrosis. Curr. Drug. Saf. 2008, 3, 67-75. [CrossRef]

165. Semyachkina-Glushkovskaya, O.; Esmat, A.; Bragin, D.; Bragina, O.; Shirokov, A.; Navolokin, N.; Yang, Y.; Abdurashitov, A.; Khorovodov, A.; Terskov, A. Phenomenon of music-induced opening of the blood-brain barrier in healthy mice. Proc. R. Soc. B 2020, 287, 20202337. [CrossRef]

166. Semyachkina-Glushkovskaya, O.; Chehonin, V.; Borisova, E.; Fedosov, I.; Namykin, A.; Abdurashitov, A.; Shirokov, A.; Khlebtsov, B.; Lyubun, Y.; Navolokin, N.; et al. Photodynamic opening of the blood-brain barrier and pathways of brain clearing. J. Biophotonics 2018, 11, e201700287. [CrossRef]

167. Lipsman, N.; Meng, Y.; Bethune, A.J.; Huang, Y.; Lam, B.; Masellis, M.; Herrmann, N.; Heyn, C.; Aubert, I.; Boutet, A.; et al Blood-brain barrier opening in Alzheimer's disease using MR-guided focused ultrasound. Nat. Commun. 2018, 9, 1-8. [CrossRef]

168. Jordão, J.F.; Thévenot, E.; Markham-Coultes, K.; Scarcelli, T.; Weng, Y.Q.; Xhima, K.; O’Reilly, M.; Huang, Y.; McLaurin, J.; Hynynen, K.; et al. Amyloid- $\beta$ plaque reduction, endogenous antibody delivery and glial activation by brain-targeted, transcranial focused ultrasound. Exp. Neurol. 2013, 248, 16-29. [CrossRef]

169. Leinenga, G.; Götz, J. Scanning ultrasound removes amyloid- $\beta$ and restores memory in an Alzheimer's disease mouse model. Sci. Transl. Med. 2015, 7, 278ra33. [CrossRef]

170. Burgess, A.; Dubey, S.; Yeung, S.; Hough, O.; Eterman, N.; Aubert, I.; Hynynen, K. Alzheimer disease in a mouse model: MR imaging-guided focused ultrasound targeted to the hippocampus opens the blood-brain barrier and improves pathologic abnormalities and behavior. Radiology 2014, 273, 736-745. [CrossRef] [PubMed]

171. Xie, L.; Kang, H.; Xu, Q.; Chen, M.J.; Liao, Y.; Thiyagarajan, M.; O’Donnell, J.; Christensen, D.J.; Nicholson, C.; Iliff, J.J.; et al. Sleep drives metabolite clearance from the adult brain. Science 2013, 342, 373-377. [CrossRef] [PubMed]

172. Fultz, N.E.; Bonmassar, G.; Setsompop, K.; Stickgold, R.A.; Rosen, B.R.; Polimeni, J.R.; Lewis, L.D. Coupled electrophysiological, hemodynamic, and cerebrospinal fluid oscillations in human sleep. Science 2019, 366, 628-631. [CrossRef] [PubMed]

173. Pavlov, A.; Dubrovsky, A.; Koronovskii, A., Jr.; Pavlova, O.; Semyachkina-Glushkovskaya, O.; Kurths, J. Extended detrended fluctuation analysis of sound-induced changes in brain electrical activity. Chaos Solitons Fractals 2020, 139, 109989. [CrossRef]

174. Pavlov, A.; Dubrovsky, A.; Koronovskii, A., Jr.; Pavlova, O.; Semyachkina-Glushkovskaya, O.; Kurths, J. Extended detrended fluctuation analysis of electroencephalograms signals during sleep and the opening of the blood-brain barrier. Chaos Interdiscip. J. Nonlinear Sci. 2020, 30, 073138. [CrossRef] [PubMed]

175. Hablitz, L.M.; Vinitsky, H.S.; Sun, Q.; Stæger, F.F.; Sigurdsson, B.; Mortensen, K.N.; Lilius, T.O.; Nedergaard, M. Increased glymphatic influx is correlated with high EEG delta power and low heart rate in mice under anesthesia. Sci. Adv. 2019, 5, eaav5447. [CrossRef] [PubMed]

176. Kiviniemi, V.; Korhonen, V.; Kortelainen, J.; Rytky, S.; Keinänen, T.; Tuovinen, T.; Isokangas, M.; Sonkajärvi, E.; Siniluoto, T.; Nikkinen, J.; et al. Real-time monitoring of human blood-brain barrier disruption. PLoS ONE 2017, 12, e0174072. [CrossRef]

177. Shuvaev, A.; Kuvacheva, N.; Morgun, A.; Khilazheva, E.; Salmina, A. The role of ion channels expressed in cerebral endothelial cells in the functional integrity of the blood-brain barrier (Review). Sovrem. Tehnol. V Med. 2016, 8, 241-250. [CrossRef]

178. Callies, C.; Fels, J.; Liashkovich, I.; Kliche, K.; Jeggle, P.; Kusche-Vihrog, K.; Oberleithner, H. Membrane potential depolarization decreases the stiffness of vascular endothelial cells. J. Cell Sci. 2011, 124, 1936-1942. [CrossRef] [PubMed]

179. Vanhatalo, S.; Voipio, J.; Kaila, K. Infraslow. EEG activity. In Niedermeyer's Electroencephalography: Basic Principles, Clinical Applications, and Related Fields; Wolters Kluwer/Lippincott Williams \& Wilkins: Philadelphia, PA, USA, $2011 ;$ pp. $741-747$.

180. Woody, C.; Marshall, W.; Besson, J.; Thompson, H.; Aleonard, P.; Albe-Fessard, D. Brain potential shift with respiratory acidosis in the cat and monkey. Am. J. Physiol. Leg. Content 1970, 218, 275-283. [CrossRef] [PubMed]

181. Revest, P.A.; Jones, H.C.; Abbott, N.J. The transendothelial DC potential of rat blood-brain barrier vessels in situ. In Frontiers in Cerebral Vascular Biology; Springer: Berlin/Heidelberg, Germany, 1993; pp. 71-74. 
182. Revest, P.A.; Jones, H.C.; Abbott, N.J. Transendothelial electrical potential across pial vessels in anaesthetised rats: A study of ion permeability and transport at the blood-brain barrier. Brain Res. 1994, 652, 76-82. [CrossRef]

183. Monto, S.; Palva, S.; Voipio, J.; Palva, J.M. Very slow EEG fluctuations predict the dynamics of stimulus detection and oscillation amplitudes in humans. J. Neurosci. 2008, 28, 8268-8272. [CrossRef]

184. Hiltunen, T.; Kantola, J.; Abou Elseoud, A.; Lepola, P.; Suominen, K.; Starck, T.; Nikkinen, J.; Remes, J.; Tervonen, O.; Palva, S.; et al. Infra-slow EEG fluctuations are correlated with resting-state network dynamics in fMRI. J. Neurosci. 2014, 34, 356-362. [CrossRef]

185. Brockett, A.T.; Kane, G.A.; Monari, P.K.; Briones, B.A.; Vigneron, P.A.; Barber, G.A.; Bermudez, A.; Dieffenbach, U.; Kloth, A.D.; Buschman, T.J.; et al. Evidence supporting a role for astrocytes in the regulation of cognitive flexibility and neuronal oscillations through the $\mathrm{Ca}^{2+}$ binding protein S100ß. PLoS ONE 2018, 13, e0195726. [CrossRef] [PubMed]

186. Bellot-Saez, A.; Cohen, G.; van Schaik, A.; Ooi, L.; Morley, J.W.; Buskila, Y. Astrocytic modulation of cortical oscillations. Sci. Rep. 2018, 8, 1-13. [CrossRef] [PubMed]

187. Henneberger, C.; Papouin, T.; Oliet, S.H.; Rusakov, D.A. Long-term potentiation depends on release of D-serine from astrocytes. Nature 2010, 463, 232-236. [CrossRef] [PubMed]

188. Takata, N.; Mishima, T.; Hisatsune, C.; Nagai, T.; Ebisui, E.; Mikoshiba, K.; Hirase, H. Astrocyte calcium signaling transforms cholinergic modulation to cortical plasticity in vivo. J. Neurosci. 2011, 31, 18155-18165. [CrossRef]

189. Bellesi, M.; de Vivo, L.; Tononi, G.; Cirelli, C. Effects of sleep and wake on astrocytes: Clues from molecular and ultrastructural studies. BMC Biol. 2015, 13, 66. [CrossRef]

190. Semyachkina-Glushkovskaya, O.; Postnov, D.; Penzel, T.; Kurths, J. Sleep as a novel biomarker and a promising therapeutic target for cerebral small vessel disease: A review focusing on Alzheimer's disease and the blood-brain barrier. Int. J. Mol. Sci. 2020, 21, 6293. [CrossRef] 